\title{
Characterization of mouse embryonic stem cell differentiation into the pancreatic lineage in vitro by transcriptional profiling, quantitative RT-PCR and immunocytochemistry
}

\author{
ALEXANDRA ROLLETSCHEK ${ }^{1, \#, ~ I N S A ~ S . ~ S C H R O E D E R ~}{ }^{1, \# \#, ~ H E R B E R T ~ S C H U L Z ~}{ }^{2}$, OLIVER HUMMEL ${ }^{2}$, \\ NORBERT HUEBNER ${ }^{2}$ and ANNA M. WOBUS*,1 \\ ${ }^{1}$ In vitro Differentiation Group, Leibniz Institute of Plant Genetics and Crop Plant Research (IPK), Gatersleben and \\ ${ }_{2}^{2}$ Max-Delbrueck Center for Molecular Medicine, Berlin, Germany
}

\begin{abstract}
We have previously shown that mouse embryonic stem (ES) cells differentiate into insulin-positive cells via multi-lineage progenitors. Here, we used Affymetrix chips and quantitative RT-PCR analysis to determine transcriptional profiles of undifferentiated wildtype (wt) and Pax4 expressing (Pax4+) ES cells and differentiated cells of committed progenitor and advanced stages. From undifferentiated to the committed stage, 237 (wt) and 263 (Pax4+) transcripts were 5- or more-fold up-regulated, whereas from the committed to the advanced stage, 28 (wt) and 5 (Pax4+) transcripts, respectively, were two- or more-fold up-regulated. Transcripts were classified into main subclasses including transcriptional regulation, signalling/growth factors, adhesion/ extracellular matrix, membrane/transport, metabolism and organogenesis. Remarkably, endoderm-specific Sox17 and early pancreas-specific Isl1 transcripts were up-regulated at an earlier stage of multi-lineage progenitors, whereas highly up-regulated probe sets and transcripts of genes involved in endoderm, pancreatic, hepatic, angiogenic and neural differentiation were detected at the committed progenitor stage. Pax4+ cells showed specific differences in transcript up-regulation and a lower amount of up-regulated neural-specific transcripts in comparison to wt cells, but no enhanced gene expression complexity. Immunocytochemical analysis of selected proteins involved in endoderm and pancreatic differentiation, such as chromogranin B, transthyretin, Foxa1 and neuronatin revealed co-expression with insulin- or C-peptide-positive cells. The comparison of transcript profiles of ES cells differentiating in vitro with those of the embryonic and adult pancreas in vivo suggested that in vitro differentiated cells resemble an embryonal stage of development, supporting the view that ES-derived pancreatic cells are unable to complete pancreatic differentiation in vitro.
\end{abstract}

KEY WORDS: mouse embryonic stem cells, transcriptional profiling, pancreatic differentiation, Pax4, Foxa1, chromogranin B, transthyretin, neuronatin

\section{Introduction}

Insulin-producing cells have been generated from embryonic and adult stem and progenitor cells (Baetge, 2008; Bonner-Weir and Weir, 2005). However, so far no insulin-secreting cell population has been produced in vitrothat would fulfil the requirements of therapeutic applications both with respect to the number of insulin-producing cells and their functional competence, specifically, glucose-responsiveness (Serup, 2006).

Embryonic stem (ES) cells [rev. (Wobus and Boheler, 2005)] are characterized by almost unlimited proliferation and the ca-

Abbreviations used in this paper: $\mathrm{ES}$, embryonic stem; Pax4+, Pax4 overexpressing; qPCR, quantitative RT-PCR; wt, wildtype.

*Address correspondence to: Dr. Anna M. Wobus. In vitro Differentiation Group, Leibniz Institute of Plant Genetics and Crop Plant Research (IPK), Corrensstr. 3, D-06466 Gatersleben, Germany. Fax: +49-39482-5481. e-mail: wobusam@ipk-gatersleben.de

Present addresses: \#Institute for Biological Interfaces (IBG), Research Center Karlsruhe (FZK), Hermann-von-Helmholtz-Platz 1, D-76344 EggensteinLeopoldshafen, Germany. \#\# Institute of Anatomy and Cell Biology, Martin-Luther-University Halle-Wittenberg, Grosse Steinstr. 52 , D-06097 Halle (Saale)

Accepted: 15 January 2009. Final author corrected PDF published online: 19 October 2009.

Supplementary Material for this paper (additional figures and tables) is available at: http://dx.doi.org/10.1387/ijdb.082694ar

ISSN: Online 1696-3547, Print 0214-6282 
pacity to differentiate into specialized progeny in vitro. Murine and human ES cells have been used to generate insulin-producing cells. Previous studies (Boyd et al., 2008; D'Amour et al., 2006; Hori et al., 2002; Kroon et al., 2008; Leon-Quinto et al., 2004; Mfopou et al., 2005; Miralles et al., 2006; Soria et al., 2000; Vaca et al., 2006) and our own data (Blyszczuk et al., 2003; Blyszczuk et al., 2004; Schroeder et al., 2006) have successfully shown the differentiation of ES cells into pancreatic cells with functional properties, thus demonstrating the proof-of-principle for the derivation of insulin-producing cells. However, strategies to select for nestin-positive cells (Lumelsky et al., 2001) showed a lower and insufficient functional level of insulin-secretion (Hansson et al., 2004; Rajagopal et al., 2003; Sipione et al., 2004) [for discussion, see (Boyd et al., 2008; Kania et al., 2004; Rolletschek et al., 2006)].

Methods including transgene over-expression [e.g. (Blyszczuk et al., 2003; Miyazaki et al., 2004; Shiroi et al., 2005)], lineage selection using pancreatic genes (Leon-Quinto et al., 2004; Soria etal., 2000), application of PI3-kinase inhibitors (Hori etal., 2002), retinoic acid [e.g. (D'Amour et al., 2006; Shi et al., 2005)] and factors from fetal pancreas [e.g. (Vaca et al., 2006)], have been used to induce ES cell differentiation into insulin-positive cells. However, high concentrations of activin A applied to human ES cells followed by sequential addition of pancreatic growth and differentiation factors have demonstrated the controlled activation of endoderm and pancreatic endocrine differentiation pathways [rev. (Bonal and Herrera, 2008)] resulting in insulin-, glucagon-, somatostatin-, PP- and ghrelin-positive cells (D'Amour et al., 2006); but the cells failed to respond to high glucose (D'Amour et al., 2006). Only the transplantation of early endocrine progenitors into diabetic mice revealed the formation of functional betalike phenotypes in vivoresulting in the normalization of high blood glucose level (Kroon et al., 2008).

By using a three-step protocol for pancreatic differentiation, we have differentiated ES cells via embryoid bodies (EBs) and multilineage progenitors into committed progenitor cells and insulinpositive cells partially representing islet-like clusters (Blyszczuk etal., 2004; Schroeder etal., 2006). Differentiated insulin-positive cells co-expressed C-peptide indicating de novo insulin synthesis. However, only ES cells constitutively expressing the pan-

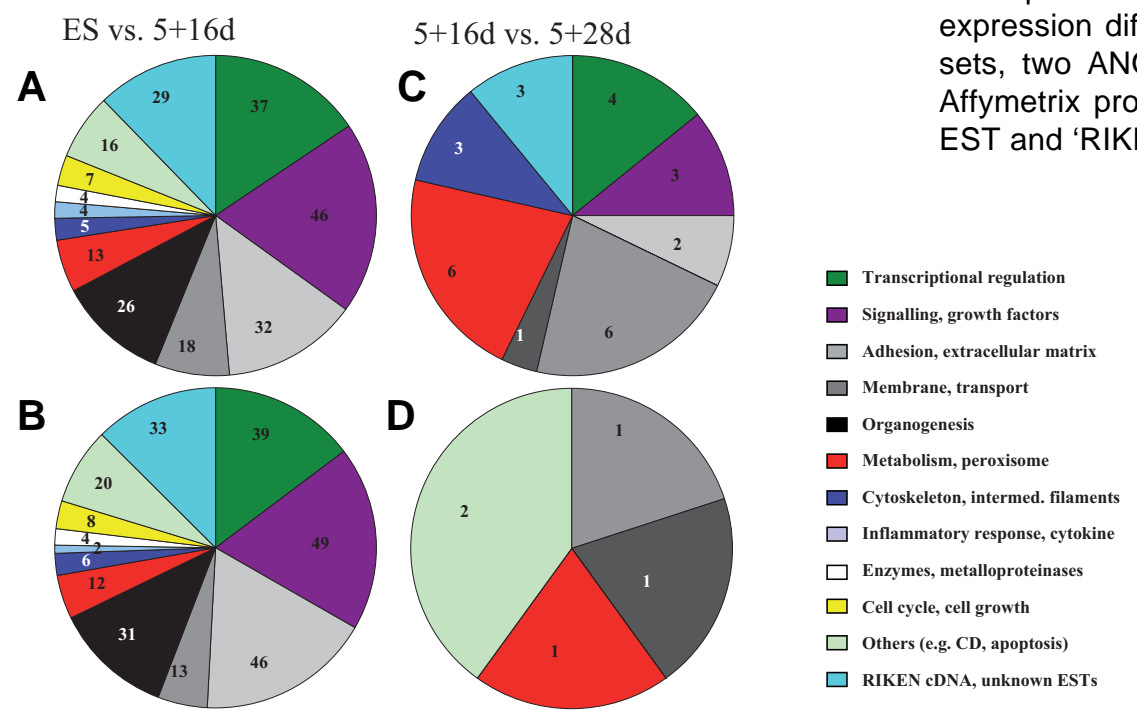

creas-specific developmental control gene Pax4 (Pax4+) developed secretory granules (electron microscopy), showed a higher insulin level (ELISA), and ion channel activity similar to neonatal $\beta$-cells (electrophysiology). After transplantation, cells of islet-like clusters partially normalized the blood glucose level of STZtreated diabetic mice (Blyszczuk et al., 2003; Blyszczuk et al., 2004; Blyszczuk and Wobus, 2004; Boyd et al., 2008).

The aim of this study performed within the integrated European Union project 'FunGenES' was to elucidate the transcriptome of Pax4+ ES-derived cells in comparison to wild-type (wt) ES cells. By cDNA microchips and transcriptional profiling we identified transcripts up-regulated in committed progenitor cells potentially involved in endoderm and pancreatic development and cell function, but also in neurogenesis. Wt and Pax4+ cells showed some qualitative and quantitative differences of transcript levels. Undifferentiated ES and differentiated ES-derived cells were further analysed by quantitative RT-PCR and transcript levels compared to fetal and adult liver and pancreas, respectively. Proteins of selected transcripts including the endocrine cell-specific storage protein chromogranin $\mathrm{B}$, the hepatic transporter protein transthyretin, the endoderm-specific transcription factor Foxa1, and neural-specific protein neuronatin were studied by immunocytochemistry and detected in ES-derived insulin- or C-peptidepositive cells.

\section{Results}

\section{Microarray analysis demonstrated significant up-regulation of transcripts in cells at the committed progenitor stage}

Three stages of wt and Pax4+ ES cells were comparatively investigated by hybridization to Affymetrix arrays: undifferentiated ES cells (stage $0 d)$, cells at the committed stage $(5+16 d)$ and cells at the advanced differentiation stage $(5+28 d)$. The rationale for choosing these timepoints was the partial co-localization of Cpeptide/cytokeratin 19, C-peptide/nestin and Isl1/nestin at the committed progenitor stage and the formation of nestin-negative C-peptide/insulin co-expressing clusters at day 5+28 [see (Blyszczuk et al., 2004)].

After passing the quality control for each array $(n=30)$, a set of robust multi-array analysis (RMA) normalized expression values were produced from wt and Pax4+ cells. To detect distinct expression differences between the conditions within the data sets, two ANOVA tests were performed. After conversion of Affymetrix probe set IDs to Genbank accessions, anonymous EST and 'RIKEN' labeled probes as well as redundancies were
Fig. 1. Pie charts demonstrating up-regulated transcripts comparing three differentiation stages, clustered by biological function. (A) Transcripts of undifferentiated wt and (B) Pax4+ES cells compared to the intermediate (committed) stage at $5+16 d$ that were five- or more- fold upregulated. (C) Transcripts of wt and (D) Pax4+ cells at the intermediate committed stage at $5+16 d$ compared to the advanced differentiation stage at $5+28 d$ that were two- or more-fold up-regulated. The absolute number of genes in each biological class is shown within each pie sector. For a complete list of up-regulated transcripts, see Suppl. Tables S2 and S4. 
removed. Analysis of the differentially expressed genes resulted in identification of 3885 (wt) and 3653 (Pax4+) transcripts. By applying a $P$ value $<10^{-6}$ data-filtering retained $243(\mathrm{wt})$ and 244 (Pax4+) up-regulated transcripts (Suppl. Fig. S2).

To further analyse the temporal gene expression during ES cell differentiation, Student's $t$-test was applied $\left(P\right.$ value $<10^{-3}$, raw data are available at http://www.ebi.ac.uk/arrayexpress/experiments/E-TABM-493. In wt cells, we identified 1441 transcripts that were two- or more-fold up-regulated in the committed progenitor cells $(5+16 d)$ compared to undifferentiated cells $(0 d)$, whereas 38 genes were two- or more-fold up-regulated in cells at the terminal stage $(5+28 d)$ compared to stage 5+16d. In Pax4+ cells, 1387 transcripts were two- or more-fold up-regulated in committed progenitors $(5+16 d)$ compared to undifferentiated ES cells, whereas five transcripts were two- or more-fold up-regulated at stage $5+28 d$ compared to stage $5+16 \mathrm{~d}$ (Fig. 1).

In order to have a high confidence that selected genes are differentially expressed, we focused on those transcripts that exhibit at least a five-fold (0d vs. $5+16 \mathrm{~d}$ ) and a two-fold upregulation $(5+16 d$ vs. $5+28 d)$ between samples. We used the mouse chip annotation as provided by the Gene Ontology (GO) consortium and performed a literature database (PubMed) search to group genes.

Based on these criteria and after subtraction of redundancies, in wt committed progenitor cells 237 genes and in Pax4+ cells 263 genes at expression levels greater than five-fold were up-regulated at stage $5+16 \mathrm{~d}$ compared to undifferentiated ES cells (Fig. 1; see Suppl. Tab. S2). Wild-type (Fig. 1A) and Pax4+ cells (Fig. $1 B)$ showed up-regulation of transcripts involved in early embryogenesis and pattern formation, especially in the subclasses 'transcriptional regulation' (wt: $n=37 /$ Pax4+: $n=39$ ), 'signalling/ growth factors' ( $n=46 / n=49)$, 'adhesion, extracellular matrix' $(n=32$ / $n=46)$ and organogenesis $(n=26 / n=31)$.

First, we searched for endoderm- and pancreas-specific transcription factors, but those transcription factors more than five-fold upregulated were not identified at stage $5+16 \mathrm{~d}$. However, at the earlier stage of multi-lineage progenitors $(5+9 d)$, we found in wt cells up-regulated transcript levels of endoderm-specific Sox17 (3.2-fold up-regulated) and early pancreas-specific Isl1 (5.7fold up-regulated) at the multi-lineage progenitor stage (5+9d, Suppl. Tab. S3, Pax4+ cells were not analysed) suggesting that endodermspecific transcription factors are expressed at an earlier stage.

We continued our analysis to transcripts up-regulated in wt and $\mathrm{Pax} 4+$ cells at the committed progenitor stage $(5+16 d)$ and identified the following members of the groups 'transcriptional regulation': nuclear receptor subfamily 2, group $\mathrm{F}$, member 1 (Nr2f1), (Nr2f2), forkhead box A1 $($ Foxa $1=H N F 3 \alpha)$, limb-bud and heart $(\angle b h)$, and transcription factor 21
(Tcf21). Some transcripts were significantly up-regulated only in wt cells: zinc finger protein of the cerebellum 1 (ZiC1), storkhead box 2 (Stox2), neuronal PAS domain protein 3 (Npas3), and oligodendrocyte transcription factor 1 (Olig1), others only in Pax4+ cells: myocyte enhancer factor 2C (Mef2C), homeobox A3 (Hoxa3), and snail homologue 2 (Drosophila, Snai2=s/ug).

In the subclass 'signaling/growth factors', transcripts of genes encoding growth factors or other signaling-related molecules were differentially expressed in wt and Pax4+ cells: pleiotrophin $(P t n)$, endothelin receptor type B (Ednrb), insulin-like growth factor binding protein 4 (Igfbp4), Igfbp 5, insulin-like growth factor 1 (lgf/), and Igf2. Transcripts of delta/notch-like EGF-related receptor (Dner) or secreted frizzled-related protein 1 (Sfrp1) were up-regulated in wt cells, whereas wingless-related MMTV integration site 5A (Wnt5a) or dickkopf homologue 2 (X. laevis, Dkk2) transcripts were found to be up-regulated only in Pax4+ cells.

A significant up-regulation of transcripts of genes involved in 'adhesion' or being part of the 'extracellular matrix' (ECM) was found for procollagens of type IV (Col4a1, Col4a2) or XI (Col11a1), decorin (Dcn), lumican ( $L u m$ ), fibrillin 2 (Fbn2), cadherins 11 and 2 (Cdh11, Cdh2), microfibrillar-associated protein 2 (Mfap2), and matrix metalloproteinase 2 (Mmp2). Only in wt cells amyloid beta (A4) precursor protein (App) and hemicentin 1 (Hmcnl) and in Pax4+ cells procollagens of type I (Col1a1, Col1a2) and type V (Col5a2), tenascin C ( Tnc) and vimentin ( Vim) were detected.

A few transcripts of genes grouped into the class of 'membrane/transport'-related proteins such as fatty-acid binding protein 7 (Fabp 7 ) and coatomer protein complex, subunit gamma 2 (Copg2) were identified in both cell lines. In wt cells transthyretin ( Ttr), chromogranin B (Chgb) and secretogranin II (Scg2), and in Pax4+ cells very low density lipoprotein receptor (VIdli) and chloride channel 4-2 (C/cn4-2) were significantly up-regulated.

Another subset of transcripts of genes involved in 'organogenesis' were significantly up-regulated in wt and Pax4+ cells, such
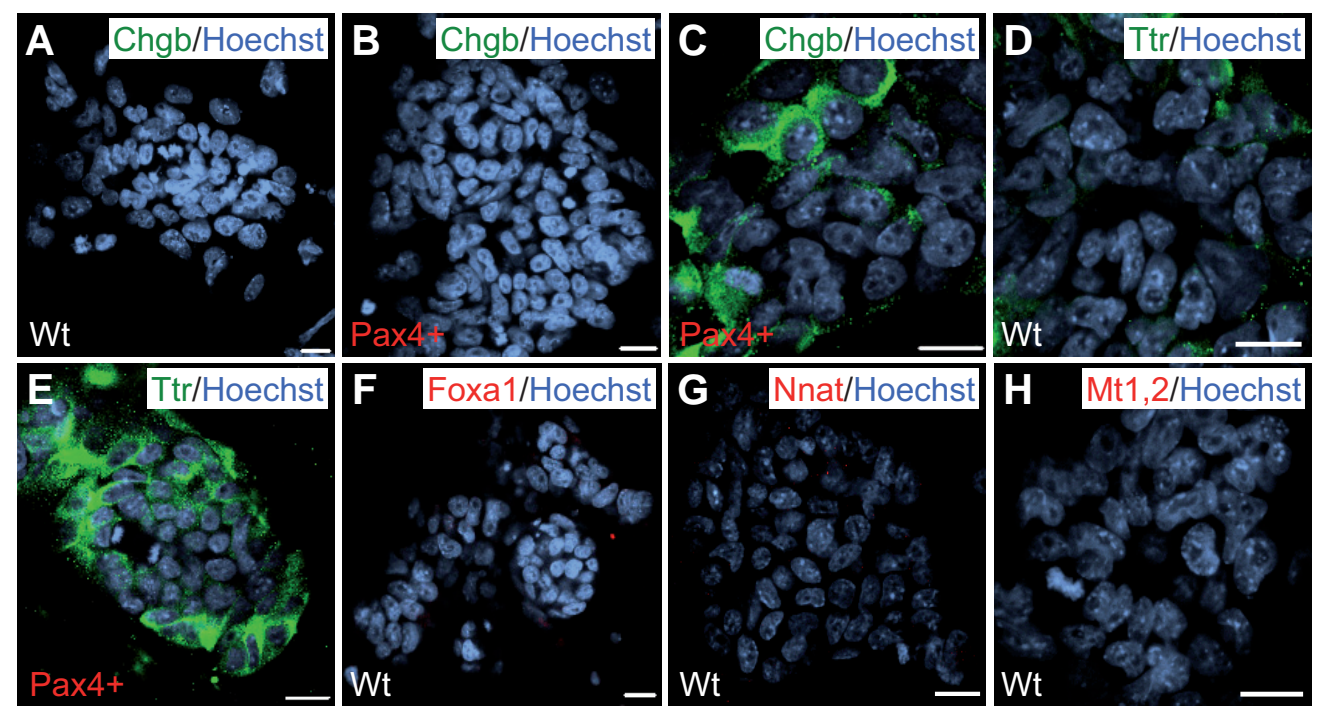

Fig. 2. Immunocytochemical analysis of five candidate markers in undifferentiated ES cells. (A) Chromogranin B (Chgb) immunoreactivity is absent in wt and most (B) Pax4+ cells, but detectable in some (C) Pax4+ES cell colonies. (D) Transthyretin (Ttr) is almost absent in wt ES cells, but showed significant immunolabelling in (E) Pax4+ cells. Wt cells were negative for (F) Foxa1, (G) neuronatin (Nnat), and (H) metallothioneins Mt 1, 2 (the antibody recognized both Mt 1 and 2). Bar, $20 \mu \mathrm{m}$. 
as neuropilin (Nrp1), endothelin receptor type A (Ednra) or quaking $(Q K)$. Wt cells showed significantly up-regulated transcripts of neuronatin (Nnat) and delta-like 1 homologue (DIk1), whereas Pax4+ cells showed significantly up-regulated transcripts of netrin1 (Ntn1) and selenoprotein N1 (Sepn1). The Suppl. Tables S2 summarize the up-regulated transcripts of all subgroups, including unknown ESTs and RIKEN cDNA.

Reasons for the differences in transcript levels between wt and Pax4+ cells may be due to statistics ( $P$ value $<10^{-3}$ and five- or more fold up-regulation between stages); and ESTs that do not fulfill these criteria would not be detected by the statistical analy-
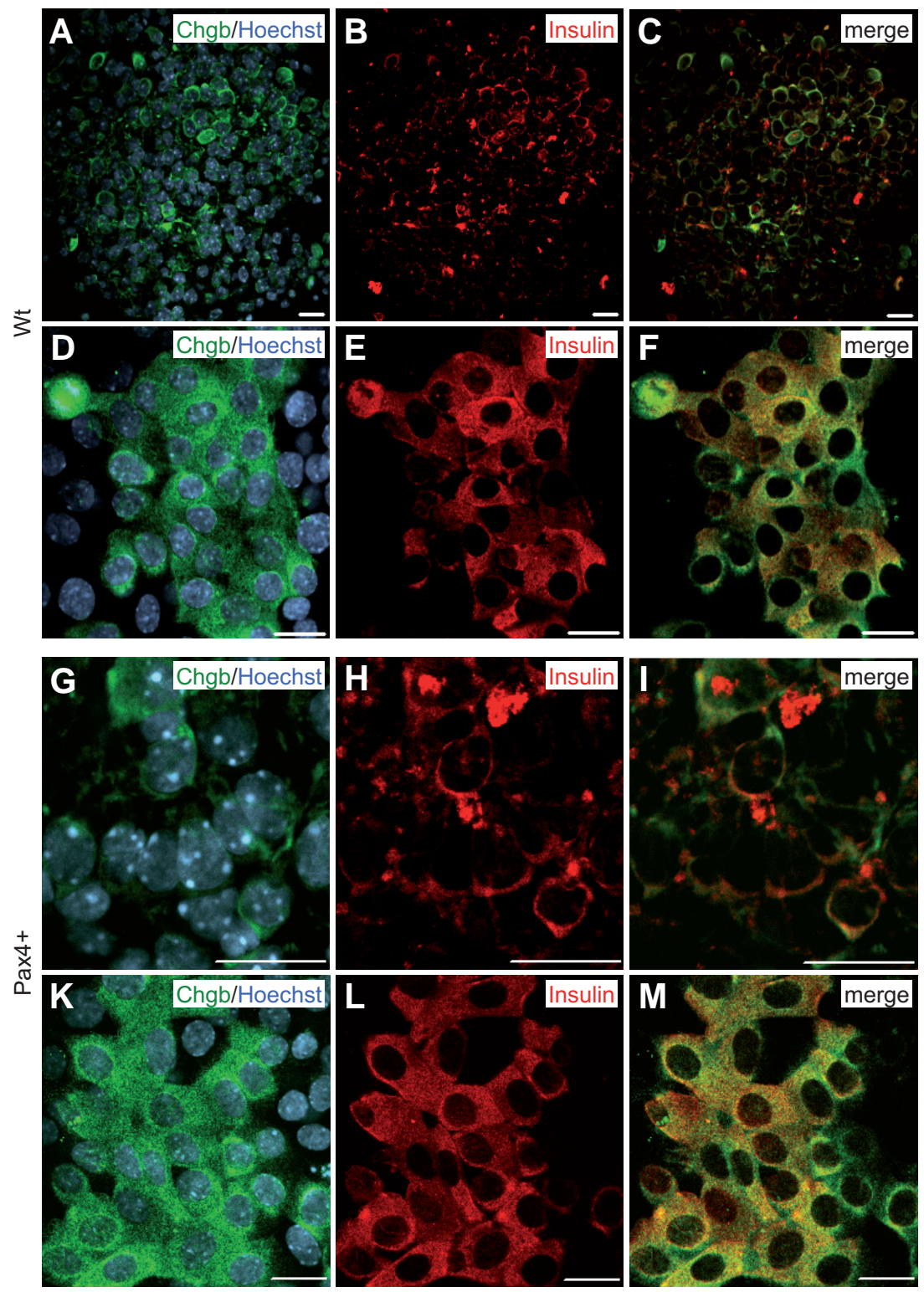

Fig. 3. Immunocytochemical analysis of chromogranin $B$ (Chgb) in ES-derived cells at stages 5+16 (A-C, G-I) and 5+28d (D-F, K-M) in wt (A-F) and Pax4+ (G-M)-derived cells. (A) Positive immunofluorescence staining of wt cells at $5+16 d$ and (D) of cells in an islet-like cluster at the advanced differentiation stage $5+28 d$ coexpressing insulin (B,E). (C) and (F) are merged images. (G) Positive immunoreactivity in few Pax4+ cells at stage of $5+16 d$ and (K) in cells of an islet-like cluster at the advanced differentiation of $5+28 d$ coexpressing insulin $(\mathbf{H}, \mathbf{L}) .(\mathbf{I}, \mathbf{M})$ Merged images. Bar, $20 \mu \mathrm{m}$.
$5+16 d$ complexity decreased with differentiation. In wh cels, 28 tran scripts were two- or more-fold up-regulated at stage $5+28 \mathrm{~d}$ in n to the progenitor stage at 5+16d (Fig. 1C, Suppl. Tab. showed a two- or more-fold up-regulation of only a few transcripts $(n=5)$ in comparison to the $5+16 d$ stage (Fig. 1D, Suppl. Tab. S4B). The number of genes involved in transcriptional regulation decreased and genes involved in maintenance of cellular function became more abundant. Transcripts were detected in the subclasses 'membrane/transport' including aquaporin 4 (Aqp4) and ceruloplasmin (Cp), 'metabolism' including metallothioneins 1, 2 and 3 (Mt1,2,3), and exclusively in Pax4+ cells, in the subclass 'apoptosis' (Nurr77, Nog2) (Suppl. Tab. S4).

Identification of up-regulated transcripts at the committed progenitor stage in comparison to transcript data from embryonic, fetal and adult pancreas in vivo

To verify the biological significance of identified transcripts, the data of in vitro differentiated cells were compared to a transcriptome study done with cells of embryonic pancreas development (Gu et al., 2004). A first comparison of ES-derived cells with early developing cells of the pancreatic lineage with respect to the spatial distribution of transcripts was performed. By comparing transcripts enriched in E7.5 endoderm with those of the ES-derived committed progenitor population, 20 (wt) and 21 (Pax4+) two- or more-fold up-regulated $5+16 \mathrm{~d}$ transcripts were detected (Suppl. Tab. S5A) including lgf2, Igfbp5, Nrp1, Foxa1, Col4a. A comparison of transcripts enriched in $\mathrm{Pdx} 1+$ pancreatic progenitor cells (E10.5) with ESderived cells revealed 15 (wt) and 7 (Pax4+) two- or more-fold up-regulated transcripts (Suppl. Tab. S5B) including Dlk1 and Chgb. Transcripts enriched in Ngn3+ endocrine progenitors (E13.5) identified by Gu et al. (2004) corresponded to 15 (wt) and 8 (Pax4+) two- or more-fold up-regulated transcripts in ES-derived cells, such as Chgb, Cpeand Ctsf(Suppl. Tab. S5C).

Next, we compared our data to the transcript profiles of early endoderm, Pdx1+ and $\mathrm{Ngn} 3+$ expressing cell stages with profiles of other stages as published by Gu et al. (2004). Transcripts enriched in Pdx1+ cells corresponded to 10 (wt) and 12 (Pax4+) up-regulated transcripts, including lgfbp5 (wt, Pax4+), Sfrp1 (wt), Col1a2/ 5a2 (Pax4+), Tnc (Pax4+) and Ptn (wt, Pax4+; see Suppl. Tab. S5E). Comparative data of other stages are shown in 
TABLE 1A

\section{TRANSCRIPT ANALYSIS OF UNDIFFERENTIATED ES CELLS COMPARED TO CELLS OF THE COMMITTED PROGENITOR STAGE AT 5+16d}

\begin{tabular}{|c|c|c|c|c|c|c|}
\hline \multirow[t]{2}{*}{ Probe set ID } & \multirow[t]{2}{*}{$\begin{array}{l}\text { Gene } \\
\text { symbol }\end{array}$} & \multirow[t]{2}{*}{ Gene title } & \multicolumn{2}{|c|}{$\begin{array}{c}\text { wt } \\
\text { ES vs. } 5+16 d\end{array}$} & \multicolumn{2}{|c|}{$\begin{array}{c}\text { Pax4+ } \\
\text { ES vs. } 5+16 d\end{array}$} \\
\hline & & & $\begin{array}{c}\text { Pax4+ } \\
\text { ES vs. } 5+16 d\end{array}$ & Quant. PCR* & Fold change & Quant. PCR* \\
\hline \multicolumn{7}{|c|}{ Transcriptional regulation } \\
\hline 1418496_at & Foxa1 & forkhead box $\mathrm{A} 1$ & 7.3 & + & 6.0 & + \\
\hline 1449397_at & Hoxb2 & homeo box B2 & 3.0 & + & 6.2 & + \\
\hline \multicolumn{7}{|c|}{ Signaling, growth factors } \\
\hline 1448254_at & Ptn & Pleiotrophin & 160.9 & + & 218.9 & + \\
\hline 1423584_at & Igfbp7 & insulin-like growth factor binding protein 7 & - & + & 20.1 & + \\
\hline 1434413_at & $\lg 1$ & insulin-like growth factor & 18.0 & + & 32.4 & + \\
\hline 1448152_at & Igf2 & insulin-like growth factor & 10.5 & + & 14.1 & + \\
\hline 1456482_at & Pik3r3 & phosphatidylinositol 3 kinase, regulatory subunit, polypeptide 3 (p55) & 6.4 & + & - & + \\
\hline 1423104_at & Irs1 & insulin receptor substrate 1 & - & $-(1.2 x$ up $)$ & 6.7 & + \\
\hline \multicolumn{7}{|c|}{ Adhesion, extracellular matriz } \\
\hline 1427884_at & Col3a1 & procollagen, type III, alpha 1 & 102.5 & + & 240.1 & + \\
\hline 1423110_at & Col1a2 & procollagen, type I, alpha 2 & - & + & 46.3 & + \\
\hline 1449368_at & Dcn & Decorin & 30.8 & + & 70.0 & + \\
\hline 1416666_at & Serpine2 & serine (or cysteine) proteinase inhibitor, clade $\mathrm{E}$, member 2 & 3.8 & + & 5.8 & + \\
\hline \multicolumn{7}{|c|}{ Membrane, transport } \\
\hline 1455913_x_at & $\operatorname{Ttr}$ & Transthyretin & 65.9 & + & - & - \\
\hline 1415885_at & Chgb & chromogranin B & 16.2 & + & - & - \\
\hline 1417900_a_at & Vldlr & very low density lipoprotein receptor & 4.7 & + & 10.7 & - \\
\hline \multicolumn{7}{|l|}{ Organogenesis } \\
\hline 1423506_a_at & Nnat & Neuronatin & 39.4 & + & - & + \\
\hline 1448943_at & Nrp1 & neuropilin 1 & 10.2 & - (1.3x up) & 35.9 & + \\
\hline \multicolumn{7}{|c|}{ Metabolism, peroxisome } \\
\hline 1415949_at & Cpe & carboxypeptidase E & 7.6 & $-(1.9 x$ up $)$ & 10.0 & + \\
\hline 1451019_at & Ctsf & cathepsin F & 2.5 & + & - & + \\
\hline 1417492_at & Ctsb & cathepsin B & - & + & 7.2 & + \\
\hline
\end{tabular}

TABLE 1B

TRANSCRIPT ANALYSIS OF CELLS AT THE COMMITTED PROGENITOR STAGE $5+16 \mathrm{~d} v s$. CELLS AT THE ADVANCED STAGE AT 5+28d

\begin{tabular}{|c|c|c|c|c|c|c|c|}
\hline \multirow[t]{2}{*}{ Probe set ID } & \multirow[t]{2}{*}{ Gene symbol } & \multirow[t]{2}{*}{ Gene title } & \multicolumn{2}{|c|}{$\begin{array}{c}\text { wt } \\
5+16 d \text { vs. } 5+28 d\end{array}$} & \multicolumn{3}{|c|}{$\begin{array}{c}\text { Pax4+ } \\
5+16 d \text { vs. } 5+28 d\end{array}$} \\
\hline & & & Fold change & Quant. PCR* & Fold change & & Quant. PCR* \\
\hline \multicolumn{8}{|c|}{ Metabolism, peroxisome } \\
\hline 1420575_at & Mt3 & metallothionein 3 & 10.4 & + & - & + & \\
\hline 1422557_s_at & Mt1 & Metallothionein 1 & 4.8 & - (1.4x up) & - & + & \\
\hline 1428942_at & Mt2 & Metallothionein 2 & 4.7 & $-(1.7 x$ up $)$ & 2.3 & + & \\
\hline \multicolumn{8}{|c|}{ Cytoskeleton, intermediate filaments } \\
\hline 1426509_s_at & Gfap & Glial fibrillary acidic protein & 46.4 & + & - & + & \\
\hline
\end{tabular}

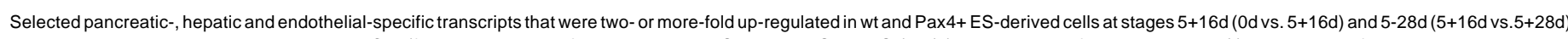

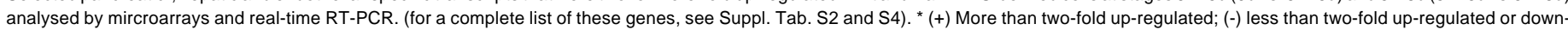
regulated (as indicated in brackets).

the Suppl. Tables S5D, F and G); and transcripts including Foxa1 (wt, Pax4+), Mafb (wt), Pik3r1 (wt, Pax4+), secretogranin II (wt) could be identified.

Because it is well known that signals/differentiation factors released by cells from other lineages have important effects on pancreatic development [rev. Bonal and Herrera, 2008; Soria, 2001)] we also compared our data set with transcriptome data of other tissue samples as done by Gu et al. (2004). Comparable to the group of transcripts enriched in Pdx1-negative cells (i.e. mesoderm surrounding the pancreas, stomach and duodenum), 25 (wt) and 29 (Pax4+) two- or more-fold up-regulated transcripts were identified (Suppl. Tab. S6A) including Dlk1 (wt), Snai2
(Pax4+), Foxa1 (wt, Pax4+), Cdh11 (wt, Pax4+), Fbn2 (Pax4+), or Col1a subunits (wt, Pax4+). Corresponding to transcripts enriched in Ngn3- negative pancreatic cells (e.g. exocrine precursors, cells of mesodermal origin within the pancreas) 37 (wt) and 41 (Pax4+) two- or more-fold up-regulated transcripts including Igf1/ 2 (wt, Pax4+), Igfbp 4/5 (wt, Pax4+), collagen subunits (wt, Pax4+), Dcn (wt, Pax4+), Lum (wt, Pax4+), and Nrp (wt, Pax4+) were detected (Suppl. Tab. S6B).

In conclusion, our oligonucleotide array analysis performed with wt- and Pax4+-derived cells revealed the majority of upregulated transcripts at the committed stage. Whereas up-regulated transcripts of definitive endoderm and early pancreas- 
specific genes (Sox17, Isl1) were already detected at the multilineage progenitor stage, we identified a remarkable number of transcripts up-regulated at stage $5+16 \mathrm{~d}$ that are associated with distinct mechanisms of endoderm and pancreas development and cell function. A number of those transcripts up-regulated in wt and Pax4+ cells corresponded to transcriptome data sets of embryonic pancreas development in vivo. However, quantitative variations of expression levels between wt and Pax4+ cells and also qualitative differences in transcript abundance were ob-
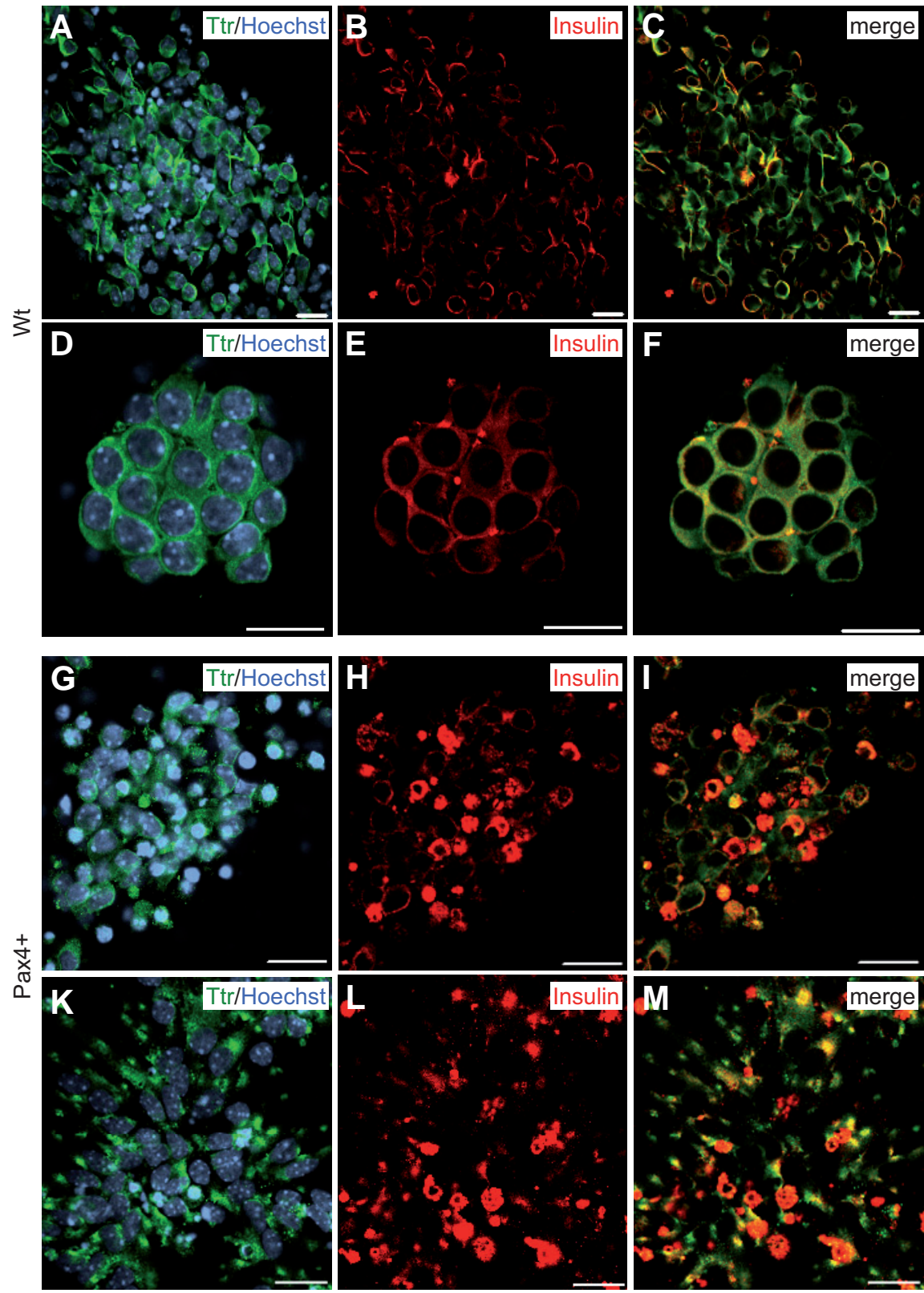

Fig. 4. Immunocytochemical analysis of transthyretin (Ttr) in ES-derived cells at stages $5+16$ (A-C, G-I) and 5+28d (D-F, K-M) in wt (A-F) and Pax4+ (G-M)-derived cells. (A) Positive immunofluorescence staining of wt cells at 5+16d and (D) of cells in an islet-like cluster at the advanced differentiation stage 5+28d coexpressing insulin (B,E). (C,F) Merged images. (G) Positive immunoreactivity in Pax4+ cells at stage $5+16 d$ and (K) in cells at advanced differentiation of $5+28 d$ coexpressing insulin $\mathbf{( H , L )}$. (I,M) Merged images. Note cells with small and condensed nuclei diplaying strong insulin staining, which represents apoptotic cells. Bar, $20 \mu \mathrm{m}$.
$5+16 d$

served between wt and Pax4+ cells.

\section{Validation of microarray data by quantitative RT-PCR (qPCR)}

A subset of genes associated with pancreatic, hepatic and endothelial cell development that showed significant up-regulain cells of the committed and advanced stages was validated CR and transcript levels were compared to those of fetal and adult pancreas, liver, and partially, brain tissue, respectively (see Table 1, Suppl. Fig. S3). In general, the data obtained by microarray analysis were confirmed by qPCR (see Tab. 1).

For specific genes we found differences in the transcript levels between wt und Pax4+ cells. Such differences in expression patterns were already evident in ES cells. Whereas most transcripts analysed showed no differences between wt and Pax4+ ES cells or were higher expressed in the wt (i.e. Irs1, Pik3r3, Col1a2, Cpe and Nrp1), Pax4+ ES cells revealed higher Chgb, Nnat, Mt1,2,3, Ttr and VIdlr transcript levels. This may reflect a correlation between Pax4overexpression and a higher level of metabolic/secretory cell function and protection against stress-induced apoptosis in Pax4+ ES cells.

Some differences between Pax4+ and wt cells could be found at the committed stage $(5+16 d)$. Most of the transcripts analysed showed higher up-regulation in wt cells, whereas several transcripts, such as Hoxb2, Ptn and Gfap were more significantly up-regulated in Pax4+ cells, or were expressed at similar levels (i.e., Nnat, Mt1,2).

However, by comparing transcriptional changes from $5+16 d$ to $5+28 d$, Pax4+ cells showed changes that more closely resemble the in vivo function of pancreatic cells, such as up-regulation of Igf1, Igfbp7, Ttr, Nrp1, Mt1,2, or have similar levels (Irs1, Chgb, Ctsb, see Suppl. Fig. S3), whereas early endoderm markers (i.e. Foxa1, Hoxb2) and neural-specific (i.e. Nnat) transcripts were down-regulated.

Comparing fetal and adult pancreas tissue, the transcripts analysed in this study showed a broad variety. Most transcripts, including Foxa1, Chgb, Mt1-3, Hoxb2, Igf2, Pik3r3, Ptn, Col1a2, Col3a1, Serpine2, Nrp1, Ctsf, and Cpe decreased during maturation from fetal to adult pancreas. Transcripts like Ttr, Nnat, Igfbp7, Irs1, Ctsb, and Gfap were up-regulated, while others (Igf1, Dcn, and VIdlr) were equally expressed in fetal and adult pancreatic tissue. 


\section{Immunocytochemical analysis of selected candidate pro- teins in ES cells}

Immunocytochemical analysis of five selected proteins was performed to verify the microarray and QPCR data and to proof their localization in C-peptide- or insulin-positive cells. The synaptic vesicle protein Chgb was selected, because Chgb is expressed in adult islets and Chgb is released by secretory granules. The hepatocyte-specific protein Ttr and transcription factor Foxa1 were studied to verify its role in ES-derived pancreatic cells. The neural-specific protein Nnat annotated for neuronal differentiation and function [see (Chu and Tsai, 2005)] was selected to discriminate between neural and pancreatic progenitors. Metallothioneins (Mt) play a role in stress response and because of up-regulated transcript levels in cells of the advanced stage, were of interest. Moreover, foxa1, ttr chgb, nnat expression has been detected in pancreas tissue or pancreas-derived cell lines, but not yet in ES-derived cells. Finally, for these five proteins, antibodies were available (lacking for other markers, such as collagen subunits, Pik3r3, serpine2 or Cpe).

Immunocytochemical analysis of Chgb in ES cells revealed its absence in undifferentiated wt (Fig. 2A) and most of Pax4+ ES cells (Fig. 2B), but localization in some Pax4+ES cells at the periphery of colonies (Fig. 2C). Ttr was weakly detected in wt ES cells (Fig. 2D), but significantly present in Pax4+ ES cells (Fig. 2E), and Foxa1 (Fig. 2F), Nnat (Fig. 2G) and Mt1,2 (Fig. $2 \mathrm{H}$ ) were not found in ES cells (Mt3 proteins could not be analysed, because Mt3-specific antibodies were not available).

Immunocytochemical analysis of Chgb, Ttr, Foxa1, Nnat and Mt1,2 in insulin- or C-peptide-positive ES-derived progeny at $5+16 d$ and $5+28 d$

Next, we analysed the localization of the five proteins in insulinor C-peptide-positive cells at committed progenitor $(5+16 \mathrm{~d})$ and advanced $(5+28 d)$ stages of differentiation (Pancreas tissue immunolabelled by insulin- and C-peptide-positive antibodies served as positive control, see Suppl. Fig. S4).

Chgb was abundant in insulin-positive cells at both stages in wt $(5+16 d$, Fig. 3 A-C) and Pax4+ (Fig. 3 G-I) cells. At stage $5+28 d$, Chgb and insulin co-localization was found in cells of islet-like clusters with no obvious morphological differences between wt (Fig. 3 D-F) and Pax4+ (Fig. 3 K-M) cells.

Fig. 5. Immunocytochemical analysis of Foxa 1 in wt ES-derived cells at stages 5+16 (A-C) and 5+28d (D-F). (A) Positive immunofluorescence staining within the cytoplasm of cells at stage $5+16 d$ and (D) of cells at the advanced differentiation stage of $5+28 d$ coexpressing $C$-peptide $(\mathbf{B}, \mathbf{E})$. Cells in insert of (D) show immunostaining of Foxa1 also in the nuclei of a subset of cells. (C,F) Merged images. Bar, $20 \mu \mathrm{m}$.
TABLE 2

NEURO-SPECIFIC TRANSCRIPTS THAT WERE TWO- OR MORE-FOLD UP-REGULATED IN WT AND PAX4+-ES-DERIVED CELLS AT THE COMMITTED STAGE (5+16D) COMPARED TO THE UNDIFFERENTIATED STAGE (OD)

\begin{tabular}{|c|c|c|c|c|}
\hline Probe set ID & Gene & Gene title & $\begin{array}{c}\text { wt } \\
\text { ES vs } 5+160 \\
\end{array}$ & $\begin{array}{c}\text { Pax } 4+ \\
\text { ES vs } 5+16 d \\
\end{array}$ \\
\hline & & & \multicolumn{2}{|c|}{ Fold change } \\
\hline \multicolumn{5}{|c|}{ Transcriptional regulation } \\
\hline 1423477_at & Zic1 & zinc finger protein of the cerebellum 1 & 77.0 & - \\
\hline 1429138_at & Npas3 & Neuronal PAS domain protein 3 & 7.0 & - \\
\hline \multicolumn{5}{|c|}{ Signaling, growth factors } \\
\hline 1448254_at & Ptn & Pleiotrophin & 160.9 & 218.9 \\
\hline 1437347_at & Ednrb & Endothelin receptor type B & 76.8 & 64.9 \\
\hline 1456379_x_at & Dner & delta/notch-like EGF-related receptor & 20.0 & - \\
\hline 1452251_at & Nbea & Neurobeachin & 11.6 & 6.5 \\
\hline 1451289_at & Dcamkl1 & $\begin{array}{l}\text { Double cortin and alcium/calmodulin- } \\
\text { dependent protein kinase-like } 1\end{array}$ & 7.7 & 24.1 \\
\hline 1455143_at & Nlgn2 & neuroligin 2 & 3.6 & 3.9 \\
\hline \multicolumn{5}{|c|}{ Membrane, transpor } \\
\hline 1450779_at & Fabp7 & fatty acid binding protein 7 , brain & 155.4 & 115.0 \\
\hline 1415885_at & Chgb & chromogranin B & 16.2 & - \\
\hline \multicolumn{5}{|c|}{ Organogenesis } \\
\hline 1423506_a_at & Nnat & Neuronatin & 39.4 & - \\
\hline 1448943_at & Nrp1 & neuropilin 1 & 10.2 & 35.9 \\
\hline 1424659_at & Slit2 & slit homolog 2 (Drosophila) & 8.4 & 11.3 \\
\hline 1418285_at & Efnb1 & ephrin B1 & 4.8 & 5.2 \\
\hline 1454974_at & Ntn1 & netrin 1 & - & 7.5 \\
\hline \multicolumn{5}{|c|}{ Inflammatory response, cytokine } \\
\hline 1448823_at & Cxcl12 & chemokine (C-X-C motif) ligand 12 & 31.6 & 22.2 \\
\hline \multicolumn{5}{|c|}{ Enzymes, metalloproteinases } \\
\hline 1433855_at & Abat & 4-aminobutyrate aminotransferase & 9.5 & - \\
\hline \multicolumn{5}{|c|}{ Cell cycle, cell growth } \\
\hline 1423100_at & Fos & FBJ osteosarcoma oncogene & 13.9 & - \\
\hline
\end{tabular}

The list contains transcripts of genes implicated in neural differentiation and neuronal cell function, which were also detected in ES-derived cells following pancreatic differentiation via multi-lineage progenitor cells [according to (Blyszczuk et al., 2004; Schroeder et al., 2006)].

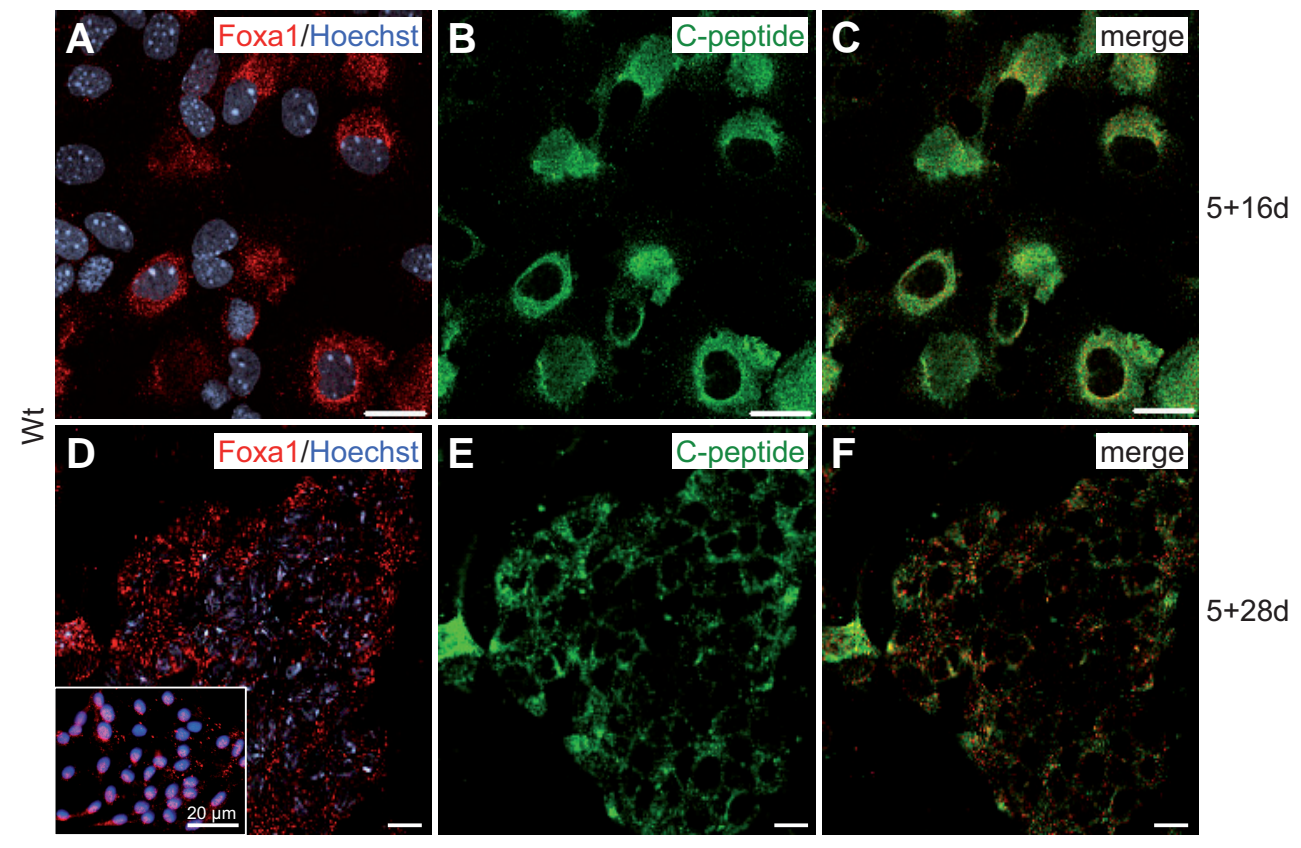


Ttr became abundant in insulin-positive wt cells at $5+16 \mathrm{~d}$ (Fig. $4 A-C)$, and co-localized with insulin-positive cells in islet-like clusters at the advanced stage (5+28d; Fig. 4D-F). Co-localization of Ttr and insulin was also found in Pax4+ committed progenitors (Fig. 4G-I) and cells at the advanced stage (Fig. $4 \mathrm{~K}$ M). However, Pax4+ cells showed signs of apoptosis with small condensed nuclei suggesting that these cells collected insulin from the medium. To verify that Ttr transcript up-regulation in ESimmunofluorescence analysis was performed with $\alpha$-fetoproteinand albumin-specific antibodies in wt and Pax4+ ES-derived cells, but no colocalization of Ttr was found with these markers (data not shown).

Foxa1 was detected in wt cells as dot-like structures in the cytoplasm, but partially, was found also in nuclei (see insert in Fig. 5D) of C-peptide-positive cells at committed progenitor $(5+16 \mathrm{~d}$, Fig. $5 \mathrm{~A}-\mathrm{C})$ and advanced (5+28d, Fig. 5 D-F) stages.

Nnat was clearly found in committed progenitors with characteristic round-shaped morphology and colocalized with insulin (Fig. $6 \mathrm{~A}-\mathrm{C}$ ). However, the fraction of immuno-positive cells decreased with differentiation; and at the advanced stage, Nnat Significant Nnat immuno-reactivity was found in cells forming neuronal extensions representing neural phenotypes (see Fig. $6 \mathrm{C}$, inset). Our data may suggest that Nnat (besides its abundance in neural cells) is also transiently expressed in a progenitorlike (bi-potential?) phenotype during pancreatic differentiation of ES cells.

The Nnat data presented here as well as the transcript data (see Table 2) demonstrate that both wt and Pax4+ cells contain a remarkable amount of neural cells suggesting that the differentiation protocol via multi-lineage progenitors induced also a neural derived cells was not due to (parallel) formation of hepatic cells, was detected in only a few insulin-positive cells (Fig. 6 D-F).

subpopulation. However, it is also evident that Pax4+ cells show a limited number and lower levels of neural transcript up-regulation in comparison to wt cells (see Table 2).

Mt1,2-specific proteins were not detected in C-peptide or insulin-positive cells, but found in the vicinity of C-peptide-positive clusters. At stage $5+16 \mathrm{~d}$, only a few Mt1,2-positive cells were present in C-peptide-negative cells (Fig. $7 \mathrm{~A}-\mathrm{C}$ ), whereas at the advanced stage, Mt1,2-positive cells were located in cells around C-peptide-positive clusters (Fig. 7 D-F).

\section{Discussion}

Transcriptional profiling of murine wt and Pax4+ ES cells induced to differentiate into pancreatic cells via multi-lineage progenitors revealed the maximum of up-regulated transcripts involved in endoderm, pancreatic, endothelial and neural differentiation at an intermediate stage of committed cells. Endodermspecific transcription factors were up-regulated at the stage of multi-lineage progenitors. A remarkable number of neural transcripts was up-regulated, specifically in wt cells. Pax4+ cells did not show higher gene expression complexity in comparison to wt cells. Endoderm- and early pancreas-specific transcripts were detected and several proteins identified in insulin-/C-peptidepositive clusters. However the advanced stage of in vitrodifferentiated ES cells did not consistently allow complete differentiation into functional pancreatic cells.

\section{Endoderm-and early pancreas-specific transcription factors were up-regulated at the early stage of multi-lineage progeni- tors}

Based on our previous findings (Blyszczuk et al., 2004), we expected to find up-regulated pancreas-specific transcription
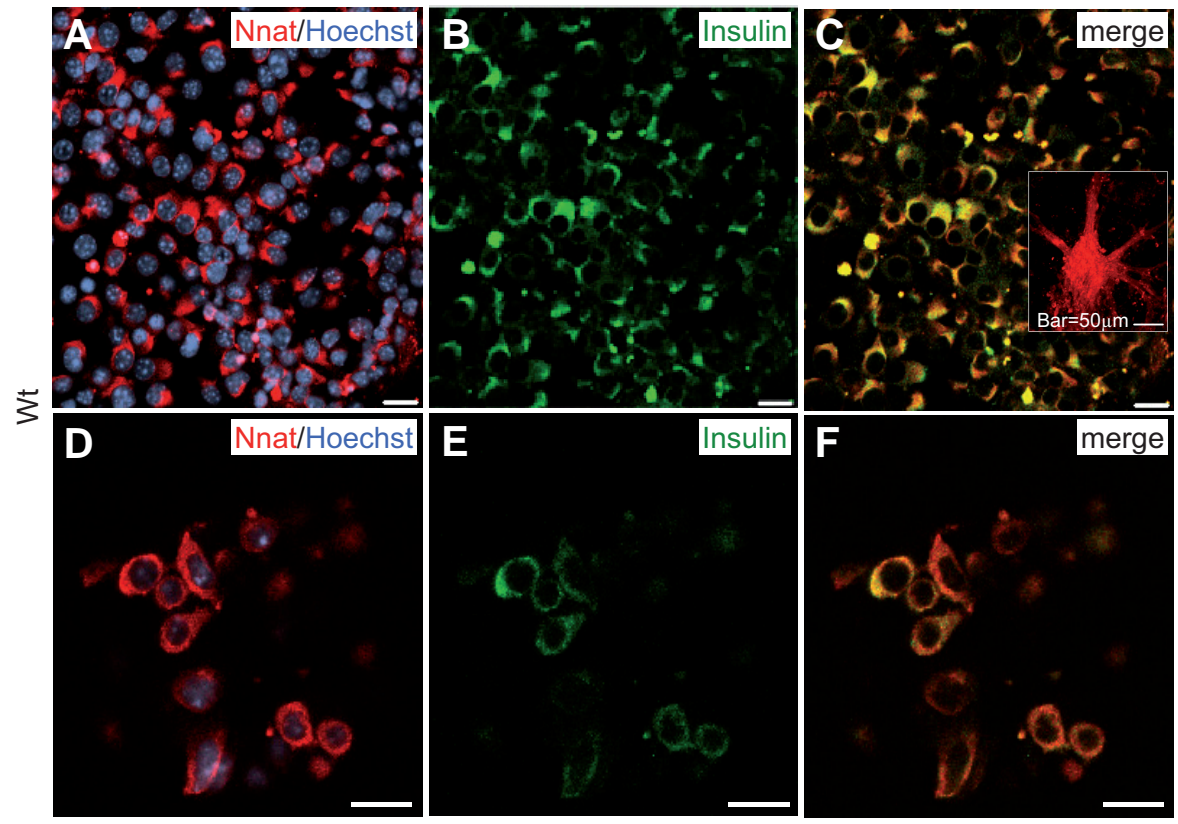
$5+16 d$ factors in the committed progenitor stage $(5+16 d)$. Reasons that we did not detect these transcription factors in the Affymetrix data set could be that (i) genes involved in early endoderm development were transiently up-regulated at lower levels, (ii) those transcripts were expressed at an earlier stage during ES cell differentiation, or (iii) transcripts were not present on the microchips. The latter explanation was true, i.e., for Pdx1 that could not be found in this study, because of absence on the Affymetrix chips. However, our previous analyses clearly demonstrated $P d x 1$ expression in differentiated wt and Pax4+ cells

5+28d (Blyszczuk etal., 2003; Blyszczuk etal., 2004).

Moreover, Sox17 and Isl1 up-regulated transcripts were detected at the earlier stage of multi-lineage progenitors. This is in agreement with findings that endoderm-specific Sox17, a Sryrelated HMG box factor is required for early pancreas specification (KanaiAzuma et al., 2002) and late-stage differentiation of extra-embryonic endo-
Fig. 6. Immunocytochemical analysis of neuronatin (Nnat) in wt ES-derived cells at stages $\mathbf{5 + 1 6}$ (A-C) and 5+28d (D-F). (A) Positive immunofluorescence staining of cells at stage $5+16 d$ and (D) of cells at the advanced differentiation stage at $5+28 d$ coexpressing insulin (B,E) Inset in (C) represents a group of neuronal cells with Nnat-labelled extensions. (C,F) Merged images. Bar, $20 \mu \mathrm{m}$ 
derm (Shimoda et al., 2007); and pancreas-specific /s/1 regulating the differentiation of islets (Ahlgren etal., 1997) is expressed in the developing pancreas and becomes restricted to endocrine cells in adult islets (Habener et al., 2005). These data underline previous data of our (Blyszczuk et al., 2004) and other (Boyd et al., 2008) groups demonstrating that ES cells during in vitrodifferentiation via multi-lineage progenitors (at least partially) pass through the endoderm lineage.

\section{The maximal number of up-regulated transcripts was present in cells at the committed progenitor stage}

We determined transcript up-regulation of genes known to play a role in endoderm and pancreatic development and function, including Hoxb2, Foxa1, Igfbp4,5, 7, Igf1,2, Irs 1, Pik3r3, procollagens Col3a1, Col4a1, Dcn, Serpine2, Ttr, Chgb, VIdlr, Nnat, Nrp1, Cpe, Ctsband metallothioneins at the stage of committed progenitors $(5+16 \mathrm{~d})$.

Hoxb2 and Foxa1 expression suggests a progenitorspecific function in ES-derived cells. Up-regulated Hoxb2 transcript levels in wt and Pax4+ cells comparable to in vivolevels of fetal pancreas and liver suggest that Hoxb2 plays a role in ES-derived pancreatic differentiation. However, Hoxb2, a downstream target of retinoic acid, has been shown to be up-regulated also in pancreatic cancer
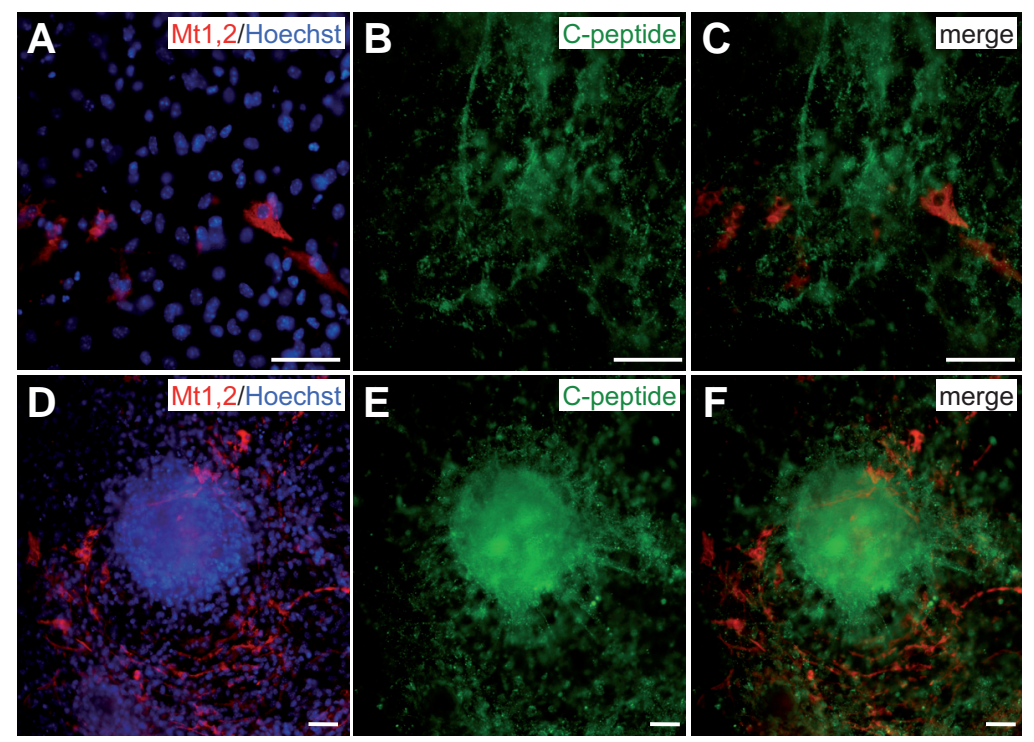

Fig. 7. Immunocytochemical analysis of metallothioneins Mt 1,2 in wt ESderived cells at stages $\mathbf{5 + 1 6}(\mathbf{A}-\mathbf{C})$ and $\mathbf{5 + 2 8 d}(\mathbf{D}-\mathbf{F})$. (A) Positive immunofluorescence staining of Mt1,2 and (B,C) C-peptide-negative cells at stage $5+16 d$ and (DF) of cells at the advanced stage of $5+28 d$. (E,F) Mt1,2 positive cells were detected in C-peptide-negative cells around C-peptide-positive clusters. Bar, $20 \mu \mathrm{m}$.
(Segara et al., 2005). The partial cytoplasmic localization of Foxa1 in C-peptide-positive cells at stage 5+16d underlined the progenitor status of the cells. Transcription factors of the Foxa family are required for cell-specific activation of glucagon in alpha-cells (Kaestner et al., 1999) and implicate a crucial role of Foxa1 in the transcriptional control of glucose homeostasis (Kaestner et al., 1999; Sharma et al., 2005). A similar regulatory function in islets has been proposed for Pik3r3, known to play a major role in the suppression of glucose-stimulated insulin secretion (Eto et al., 2002).

The transcriptome analysis detected up-regulated transcript levels of $\lg f 1,2$ and $\lg f b p 4,5,7$, which are temporally and spatially expressed during pancreas development [rev. (Hill et al., 1998)]. Protein abundance in beta cells supports an important role of the Igf/Igfbp system in endocrine pancreatic maturation, and the determination of beta-cell mass and insulin availability (Hill et al., 1999). Igf1,2, are part of a complex system regulating beta-cell growth and function (Katz et al., 1997). Irs1 mediates metabolic and growth-promoting activity of insulin and Igf1, and the Irs1 pathway modulates insulin secretion in pancreatic beta cells (Burks and White, 2001).

Within the group of adhesion and ECM proteins, transcripts of genes encoding procollagens (i.e. Co/3a1, Col4a1) were upregulated consistent with the in vivo situation, where collagens are the main ECM components of the islet microenvironment (Kaido et al., 2004). Decorin (Dcn) belongs to the group of small leucine-rich proteoglycans expressed by sprouting endothelial cells. Decorin plays a role in regulating collagen fibril formation and stabilization, and modulates cell adhesion as well as transforming growth factor- $\beta$ activity [for review see (Koninger et al., 2004; Kresse and Schonherr, 2001)]. Dcn transcripts were upregulated in committed progenitor cells, but not in liver and pancreas. A functional role of Dcn in pathological mechanisms, i.e. inhibition of tumour cell growth, was described by Kresse and
Schonherr (2001) and Koninger et al. (2004).

Serpine2 transcripts were slightly up-regulated in committed progenitor cells, whereas significant levels were detected in adult pancreas. Serpine 2 regulates protease activity in smooth muscle and prostate cancer cells and is an important modulator of tumorhost interaction in pancreatic cancer (Buchholz et al., 2003), but we have no explanation for the high serpine2 levels in adult pancreas.

The transcript up-regulation of Ttrin wt cells of the committed progenitor stage was unexpected, because the gene has been annotated for hepatic differentiation and liver function, but not yet for ES-derived pancreatic cells. Ttr, a transport protein for thyroxin or retinol is synthesized in the liver, brain and endocrine pancreas (Jacobsson et al., 1989; Kato et al., 1985). A potential role of Ttr in pancreatic cells has been described by Refai et al. (2005) who demonstrated a promoting effect for glucose-induced increase of cytoplasmic $\mathrm{Ca}^{2+}\left(\left[\mathrm{Ca}^{2+}\right]_{\mathrm{i}}\right)$ and insulin release due to direct Ttr effects on glucose-induced electrical activity (Refai et al., 2005). The authors postulated a protective role of Ttr against beta cell apoptosis. The presence of Ttr in undifferentiated Pax4+ ES cells (Fig. 2E) and cells of the advanced stage (see Fig. 4; Suppl. Fig. S3) may suggest a similar role in ES cells in vitro.

We further identified characteristic proteins of the pancreatic endocrine secretory pathway (Karlsson, 2001), such as Chgband secretogranin II (Scgl/= chromogranin C) in in vitro differentiated ES cells. Chgb is known to bind calcium (Gorr et al., 1989), exert trophic activity in neurons (Chen et al., 1992) and mediate the sorting of peptide hormones to the secretory granules (Natori and Huttner, 1996). The presence of variable Chgb epitopes in endocrine pancreatic cell types suggests that different Chgb epitopes are expressed in different cell types (Portela-Gomes and Stridsberg, 2002), and besides Chgb, secretory granule-specific Scgll levels were up-regulated in wt cells. Scgll is highly expressed in alpha cells (Boonen et al., 2007) and shown to be 
enriched in mature islets (see Suppl. Tab. S5G; Gu et al., 2004). Scgll and Chgb up-regulation and Chgb colocalization with insulin in both wt and Pax4+ ES-derived cells suggests that the cells attained, at least partially, a pancreatic fate in vitro.

The very low density lipoprotein receptor (VIdli) has been detected in pancreatic islets (Roehrich etal., 2003) and correlated with the survival of beta cells (Cnop et al., 2002), but we have no explanation for high Vldlr levels in Pax4+ ES cells.

Neuronatin (Nnat) and neuropilin (Nrp1), members of the subgroup "organogenesis" were also up-regulated in ES-derived committed cells in vitro, consistent with in situhybridization data showing Nnat expression in the pancreas of mouse E14.5 and E16.5 embryos (Chu and Tsai, 2005). Although Nnat is highly expressed in postmitotic neurons and in neonatal and adult brain (Joseph et al., 1994) [rev. (Gavazzi, 2001)], Nnat is also expressed in other adult tissues, such as pituitary and adrenal glands, lung, uterus, skeletal muscle, ovary and pancreas (Arava et al., 1999; Niwa et al., 1997). Nnat was determined as a downstream target of NeuroD/BETA2 in the pancreas playing a role in glucose-mediated insulin secretion (Chu and Tsai, 2005). The presence of Nnat protein in insulin-positive committed progenitor cells suggests a role of Nnat in ES cell differentiation. But, transcript and protein abundance at the advanced stage and presence in neural cells points also to the induction of neural phenotypes during ES cell differentiation via multi-lineage progenitors [see (Blyszczuk and Wobus, 2004; Rolletschek et al., 2006).

Three members present in the secretory compartment of islets were also detected in ES-derived cells, such as cathepsin B [Ctsb; (Kuliawat et al., 1997)], cathepsin F [Ctsf; (Gu et al., 2004)] and carboxypeptidase E [Cpe; (Marzban et al., 2005)]. The metabolic enzyme Cpe is involved in processing of pro-islet amyloid polypeptide in beta cells (Marzban et al., 2005), whereas Ctsb is involved in proteolytic cleavage within secretory granules (Conlon et al., 1995). The presence of cathepsins and carboxypeptidase suggests that mechanisms involved in insulin and IAPP processing in vivo may play a role in ES-derived pancreatic progenitors.

Metal-binding metallothioneins $(M t) 1,2$ are expressed in acinar, ductal (De Lisle et al., 1996) and beta (Chen etal., 2001) cells. Remarkably, Mt1,2,3 transcripts were up-regulated in Pax4 undifferentiated ES cells, and Mt1,2 transcripts were increased in committed progenitors, but specifically in cells at the advanced stage (whereas the neural-specific Mt3 was detected at lower level in Pax4+ cells). In the pancreas, metallothioneins are present in acinar cells, pancreatic ducts (De Lisle et al., 1996) and beta cells (Chen et al., 2001) and are supposed to play a role in zinc homeostasis and protection against reactive oxygen species [ROS; (Chen et al., 2001)]. The up-regulation of metallothioneins and their close localization around $\mathrm{C}$-peptide-positive clusters (see Fig. 7 D-F) suggests a role in support of beta-cell-specific functions and/or a role in (ROS-dependent?) stress-response.

The significant up-regulation of the intermediate filament protein GFAP, a characteristic cytoskeletal protein of astrocytes [rev. (Eng et al., 2000)] would suggest that ES-derived cells at the advanced stage are GFAP-positive astrocytic cells and partially represent neural cell types (see below). However, this population may also represent a type of stellate-like cells present in (adult) pancreas and (fetal) liver. Stellate cells are expressed in response to tissue damage (Bachem et al., 1998) and are positive for mesenchymal and neural markers.

\section{Neural-specific transcripts were up-regulated in wt cells, but at lower level in Pax4+ cells}

The microarray analysis demonstrated a significant up-regulation of transcripts involved in neurogenesis and neuronal cell function including the zinc finger protein of the cerebellum1 (ZiC1), neuronal PAS domain protein3 (Npas3), Nnat, pleiotrophin (Ptn), endothelin receptor type B (Ednrb), neuroligin2 (N/gn2), Nrp1 and Gfap (see Tab. 2). However, only 11 neural-specific transcripts were up-regulated in Pax4+ cells, instead of 17 in wt cells, suggesting that Pax4+ cells are more committed to a pancreatic fate than wt cells.

The expression of neural-specific developmental control genes during pancreas development (i.e. Is/1, ngn3, NeuroD1, Pax6) is relevant for ES cells differentiating into pancreatic and neural lineages (Roche et al., 2005; Rolletschek et al., 2006; Soria, 2001). The neural stem/progenitor cell-specific protein nestin was also detected during in vitrodifferentiation of ES cells [i.e. (Lumelsky et al., 2001); see (Blyszczuk et al., 2003; Blyszczuk et al., 2004)] and islets (Zulewski et al., 2001), but selection of ES-derived nestin-positive cells was not efficient in generating islet-like cells (Hansson et al., 2004; Kania et al., 2004; Rajagopal et al., 2003). Whereas in vivo development assures gene expression in a spatially and temporally regulated manner, during in vitrodifferentiation of ES cells, cell types of all somatic lineages (= multilineage progenitors) are present in the EB outgrowths. This could explain the insufficient pancreatic differentiation of ES cells via neural cell types [see (Hansson et al., 2004; Sipione et al., 2004)] and requires the application of specific selective differentiation methods as recently presented by D'Amour et al. (2006) and Kroon et al. (2008).

Lineage tracing studies demonstrated, however that neural progenitor cells may have the capacity to differentiate into both neural and pancreatic lineages (Seaberg et al., 2004) and would suggest the idea of a pancreatic progenitor cell type defined by both neural (ectoderm) and pancreas (endoderm)-specific properties.

\section{Pax4+ cells revealed some diversity in comparison to wt cells and showed signs of apoptosis at the advanced stage}

The present data revealed differences between the transcriptomes of wt and Pax4+ that were up-regulated from ES cells to the committed stage. For example, in many subgroups (transcriptional regulation; signalling/growth factors; adhesion, $\mathrm{ECM}$; organogenesis) a higher number of transcripts were upregulated in Pax4+ compared to wt cells (see Fig. 1). However, the verification of transcriptome data by qPCR revealed only Hoxb2, Ptn and Mt1,2 (genes involved in pancreas development/ function) as up-regulated transcripts in Pax4+ cells, whereas generally, more up-regulated transcripts were found in wt cells. Reasons for these dissimilarities may be: (i) Pax4+ cells expressed less neuronal transcript numbers (see Table 2), (ii) transcripts had a $P$ value $>10^{-3}$ in Pax4+cells [i.e. Chgb $(p=0.003)$, $\operatorname{Ttr}(p=0.02), \operatorname{Scgb}(p=0.002), \operatorname{Itm} 2 a(p=0.0012)]$, and therefore, did not fulfill the cutoff value of statistical analysis, and (iii) Transcripts were less than five-fold up-regulated, e.g. in wt cells VIdlr (4.7 fold up), Clcn4-2 (4.2 fold up).

However, our study also clearly demonstrated a relatively low 
number of up-regulated transcripts from the committed to the advanced stage. We may speculate about fate-restricted conditions of cells at the advanced stage, specifically in Pax4+ cells (see Fig. 1), whereas cells at $5+16 d$ represent a progenitor cell population. Specifically, Pax4+ cells showed no signs of higher maturation, but rather signs of apoptosis, such as transcript upregulation of the Nurr77 downstream gene 2 [Ndg2, (Rajpal et al., 2003)], cytochrome c testes (Cyct) and apoptotic phenotypes (see Fig. 4 G-M). As demonstrated by Brun and coworkers, Pax4 over-expression in beta-cells caused an increase of proliferation paralleled by increased Bcl-xL (anti-apoptotic), c-myc and Id2 mRNA levels, while Bcl-xL activity resulted in altered mitochondrial calcium level and impaired glucose-induced insulin release (Brun et al., 2004). In our studies, Pax4+-derived cells showed signs of metabolic starvation at the advanced stage presumably because of higher proliferation of the cells [see (Blyszczuk et al., 2003; Blyszczuk et al., 2004), although daily medium changes were performed during advanced cultivation stages.

\section{Comparison of transcriptomes of ES-derived cells and of tissue samples suggest an embryonic/ fetal developmental stage}

The comparison of expression levels of in vitro differentiated ES-derived cells with transcript levels of fetal and adult pancreas revealed that many genes, such as Foxa1, Hoxb2, Ttr, Igf1, Irs 1, Chgb, cathepsin B (Ctsb) and F (Ctst), carboxypeptidase E (Cpe) and Mt 1and 2 were expressed at levels comparable to levels of the fetal pancreas. The comparison of our data with a transcriptome analysis of cells isolated from pancreas during development ( $\mathrm{Gu}$ et al., 2004) revealed partial overlapping gene functions. Comparable to the group of genes enriched in E7.5 endoderm in vivo, we detected Igf2, Igfbp5, Nrp1, Foxa1, Pem, Col4a1; within the group of Pdx1-positive E10.5 pancreatic progenitor cells Dlk1 and $\mathrm{Chgb}$; and in the group of E13.5 Ngn3-positive endocrine progenitors Chgb, Cpe and Ctsf.

Although we have to consider that in the study by $\mathrm{Gu}$ et al. (2004) other microarray chips have been used, our data suggest that ES-derived cells after in vitro differentiation show some endoderm- and pancreas-specific markers, but do not represent mature pancreatic cells.

While ES-derived cells differentiating via multi-lineage progenitors (our study) attained partial functional competence in vivo after transplantation into diabetic mice as shown by Blyszczuk et al. (2004) and Boyd et al. (2008), the present data as well as recent studies (Kroon et al., 2008) led us to conclude that ESderived cells are unable in vitroto pass through terminal differentiation stages into functional islet-like cells. The formation of glucose-responsive insulin-producing cells was only shown to proceed in vivo, if pancreatic endocrine progenitor cells were transplanted (Kroon et al., 2008). Obviously, to differentiate into functional beta-cells, endocrine and pancreatic progenitors need additional (not yet identified) factors that are not available for in vitro differentiation.

\section{Material and Methods}

\section{Cell culture and differentiation}

ES cells of line R1 [wt, (Nagy et al., 1993)] and R1 ES cells constitutively expressing Pax4[Pax4+, (Blyszczuk et al., 2003)] were cultured on embryonic fibroblast feeder layers in Dulbecco's modified Eagle's medium and supplements as described (Blyszczuk et al., 2004; Wobus et al., 2002). The cells were passaged at least three times without feeders before use in the experiments to minimize the feeder cell content. The three-step protocol of pancreatic differentiation (Suppl. Fig. S1) included (i) the formation of embryoid bodies (EBs), (ii) after EB plating on adhesive substrates the expansion and spontaneous differentiation to form multilineage progenitors and (iii) after dissociation of progenitor cells, differentiation induction into the pancreatic lineage and formation of islet-like clusters (Blyszczuk et al., 2004; Schroeder et al., 2006).

In short, Pax $4+$ and wt ES cells $(n=600$ cells $/ 20 \mu$ l) were plated on the lids of Petri dishes $(\varnothing 10 \mathrm{~cm})$, cultured as 'hanging drops' for 2 days and on bacteriological plates $(\varnothing 6 \mathrm{~cm})$ in suspension for 3 days to form EBs. At day 5, EBs were plated in Iscove's modified Dulbecco's medium (IMDM; Invitrogen, Karlsruhe, Germany) supplemented with $20 \%$ FCS (selected batches, Invitrogen), $2 \mathrm{mM}$ L-glutamine (Invitrogen), nonessential amino acids (1:100 of stock solution, Invitrogen), $\alpha$-monothioglycerol (final concentration $450 \mu \mathrm{M}$; Sigma, Steinheim, Germany) and penicillin/streptomycin (1:100 of stock solution, Invitrogen) (differentiation medium I). For spontaneous differentiation into multi-lineage progenitors, the EB outgrowths were cultured for another 9 days in differentiation medium I. At day $5+9$, cells were dissociated by $0.1 \%$ trypsin (Invitrogen): $0.08 \%$ EDTA (Sigma) in PBS (1:1) for 1 min, collected by centrifugation and replated onto poly-L-ornithine/laminin-coated tissue culture dishes in 'N2 medium + NA' containing DMEM/F12 (Invitrogen) supplemented by $20 \mathrm{nM}$ progesterone, $100 \mu \mathrm{M}$ putrescine, $1 \mu \mathrm{g} / \mathrm{ml}$ laminin, $25 \mu \mathrm{g} / \mathrm{ml}$ insulin, $30 \mathrm{nM}$ sodium selenite, $10 \mathrm{mM}$ nicotinamide (NA) (all from Sigma), $50 \mu \mathrm{g} / \mathrm{ml}$ transferrin, B27 media supplement (dilution 1:50) (all from Invitrogen) and 15\% FCS (= differentiation medium II). At day $5+10$, the medium was replenished and cells were cultivated in differentiation medium II without FCS up to the stage $5+16 \mathrm{~d}$ (stage of committed progenitors) and $5+28 \mathrm{~d}$ (islet-like clusters) for analysis [see (Blyszczuk et al., 2004; Schroeder et al., 2006)].

\section{cRNA probe generation and hybridization to Affymetrix microarray chips}

Total RNA of Pax4+ and wt cells from five independent experiments was isolated from undifferentiated ES cells $(0 \mathrm{~d})$, multi-lineage progenitor cells (5+9d; only wt cells), committed progenitor cells $(5+16 d)$ and cells at the terminal differentiation stage $(5+28 d)$, respectively. The RNeasy Mini Kit (Qiagen, Hilden, Germany) was used according to the manufacturer's instructions with on-column DNase treatment (RNase-free DNase Set; Qiagen) for 60 min to avoid genomic DNA contamination. RNA quality was measured as a function of the ratio of absorbance at 260 and $280 \mathrm{~nm}$. Furthermore, all RNA samples were analysed using agarose gel electrophoresis and stained to check for integrity of 18 S and 28S RNA. Biotinylated cRNA was prepared according to the standard Affymetrix protocol (Expression Analysis Technical Manual, 1999; Affymetrix, Santa Clara, USA). Douple-stranded cDNA was synthesized from $10 \mu \mathrm{g}$ total RNA using the SuperScript Choice System (Invitrogen) and the T7-(dT)24 primer (Affymetrix). Following a phenol/chloroform extraction and ethanol precipitation, the cDNA was transcribed into biotin-labelled cRNA using the Retic Lysate IVT'M kit (Ambion Inc., Austin, TX, USA). The cRNA product was purified using the RNeasy kit (Qiagen) and fragmented to an average size of 30-50 bases according to Affymetrix recommendations. Fifteen micrograms of fragmented cRNA were hybridized for $16 \mathrm{hr}$ at $45^{\circ} \mathrm{C}$ on the Mouse Genome 4302.0 Array. The arrays were washed and stained in the Affymetrix Fluidics Station 450 and further scanned using the GeneChip ${ }^{\circledR}$ Scanner 3000 (Affymetrix).

\section{Data normalization and expression profiling}

Quality control was performed by using the GCOS 2 software package, its noise and background estimation and the 3' to 5' expression ratios of the housekeeping genes GAPDH and $\beta$-actin. After passing the quality control a set of robust multi-array analysis (RMA) normalized expression 
values was produced using RMAexpress 0.2 (Bolstad et al., 2003). An outlier in the sets of five biological replicates per condition was detected and removed applying the Nalimov test at $P<10^{-3}$. ANOVA were performed to detect general expression differences dependent on differentiation stages. Expression profiles were examined by hierarchical cluster analysis using Cluster version 2.11 (Eisen et al., 1998) applying meancentring and normalization of genes and arrays before average linkage clustering with un-centred correlation. A Student's $t$-test (unpaired, assuming unequal variances) $P$ value $<10^{-3}$ and a fold change $>2$ between two conditions was applied to define differential expression. In the case of multiple gene to probe set assignment (redundancy), the probe set with the highest maximum signal value over all tested arrays was selected. An intersection of up-regulation in committed progenitors $(5+16 \mathrm{~d})$ compared with undifferentiated ES cells (0d) (five-fold, $t$-test $P$ value $<10^{-3}$ ) and compared with cells at the terminal differentiation stage $(5+28 \mathrm{~d})$ (two-fold, $t$-test $P$ value $<10^{-3}$ ) was used to identify up-regulated transcripts at advanced stages of pancreatic differentiation.

\section{Quantitative (q) RT-PCR analysis}

Total RNA of a separate set of experiments $(n=3)$ was isolated by the RNeasy Mini Kit method as described above, and reverse transcribed using previously published protocols (Schroeder et al., 2006; Wobus et al., 2002). In addition, total RNA was prepared from fetal (E16 d p.c.) and adult ( 2 months age) tissue of liver, pancreas and brain. Changes in mRNA levels of specific genes were quantified using the ABI PRISM 7900 HT Sequence Detection System (Applera, Darmstadt, Germany). A set of specific oligonucleotide primers (Suppl. Tab. S1) was designed using Primer Express software 2.0 (Applera). Briefly, amplification of the target genes was monitored via SYBR ${ }^{\mathrm{TM}}$ green fluorescence signals generated during each PCR cycle. Fluorescence signals were regarded positive if the fluorescence intensity reached 10x the standard deviation of the baseline fluorescence (threshold). The amplification mix was prepared following the SYBR green PCR master mix (Applied Biosystems, Warrington, UK) protocol. Primers were used in a concentration of 100 $\mathrm{nM}$. Each reaction was performed in triplicate in 96-well optical reaction plates under the following conditions: $50^{\circ} \mathrm{C}$ for $2 \mathrm{~min}, 95^{\circ} \mathrm{C}$ for $10 \mathrm{~min}$, followed by 50 cycles of $95^{\circ} \mathrm{C}$ for $15 \mathrm{~s}$ (denaturation) and $60^{\circ} \mathrm{C}$ for $1 \mathrm{~min}$ (annealing/extension). Relative mRNA levels were calculated using the standard curve method (see User Bulletin \#2; Applied Biosystems).

\section{Immunohistochemistry and immunofluorescence analysis}

Whole pancreas tissue of eight weeks old mice were fixed in $4 \%$ paraformaldehyde (PFA) in PBS overnight. After fixation, samples were dehydrated in graded alcohol for $2 \mathrm{hr}$ each $(70 \%, 80 \%$, and $96 \%$ ethanol, isopropanol, and xylene) and embedded in hot paraffin $\left(60^{\circ} \mathrm{C}\right)$. Pancreas were sectioned in $5 \mu \mathrm{m}$ strength using a microtome (Medim, Zug, Switzerland) and mounted on silanized slides. For immunofluorescence, the sections were de-paraffinized overnight at $60^{\circ} \mathrm{C}$ and rehydrated through a series of graded alcohols.

Tissue sections, ES cells, and EB-derived cells growing on cover slips were fixed by $4 \%$ PFA or $0.1 \%$ glutaraldehyde in $4 \%$ PFA at room temperature (RT) for $20 \mathrm{~min}$, respectively, and processed for immunofluorescence analysis as described (Schroeder et al., 2006). Hoechst 33342 $(5 \mu \mathrm{g} / \mathrm{ml}, \mathrm{RT}, 10 \mathrm{~min})$ was used to label the nuclei. The following primary antibodies (dilution 1:100) were used: Mouse anti-insulin IgG (clone K36AC10, Sigma-Aldrich, Hamburg, Germany), sheep anti-C-peptide, rabbit anti-chromogranin B (both from Acris, Hiddenhausen, Germany), goat anti-neuronatin (S-14, Santa Cruz Biotechnology, Heidelberg, Germany), sheep anti-prealbumin (= transthyretin, Biodesign, Saco, ME, USA), rabbit anti-Foxa1 (Chemicon, Hampshire, UK), mouse anti- $\alpha$ fetoprotein, mouse anti-metallothionein (Mt) IgG (specific for Mt subunits 1,2; Invitrogen) and rabbit anti-albumin (Abcam, Cambridge, UK).

The following secondary antibodies were used according to the manufacturers' recommendations: Cy3 anti-mouse IgG, Cy3 anti-rabbit, Cy3 anti-goat (all from Jackson ImmunoResearch Laboratories, West
Grove, PA, USA), Alexa 488 anti-mouse IgG, Alexa 488 anti-sheep, Alexa 488 anti-rabbit (all from Molecular Probes, Karlsruhe, Germany). Samples were analysed by the fluorescence microscope ECLIPSE TE300 (Nikon, Japan) and the confocal laser scanning microscope LSM 510 META (Carl Zeiss, Jena, Germany).

\section{Acknowledgements}

We are grateful to Mrs. S. Sommerfeld, O. Weiss, K. Meier, K. Deist and $K$. Seiffert for excellent technical assistance. We thank Dr. A. Navarrete Santos for providing us pancreatic tissue sections. The work was financially supported by grants from the German Research Foundation (DFG, WO 503/3-3) and by the European Union within the Project FunGenES (LSHG-CT-2003-503494) to A. M.W.

\section{References}

ABI PRISM 7700 Sequence Detection System. User Bulletin \#2. http:// www.appliedbiosystems.com

AHLGREN, U., PFAFF, S. L., JESSELL, T. M., EDLUND, T. and EDLUND, H. (1997) Independent requirement for ISL1 in formation of pancreatic mesenchyme and islet cells. Nature 385: 257-260.

ARAVA, Y., ADAMSKY, K., EZERZER, C., ABLAMUNITS, V. and WALKER, M. D. (1999) Specific gene expression in pancreatic beta-cells: cloning and characterization of differentially expressed genes. Diabetes 48: 552-556.

BACHEM, M. G., SCHNEIDER, E., GROSS, H., WEIDENBACH, H., SCHMID, R. M., MENKE, A., SIECH, M., BEGER, H., GRUNERT, A. and ADLER, G. (1998) Identification, culture, and characterization of pancreatic stellate cells in rats and humans. Gastroenterology 115: 421-432.

BAETGE, E. E. (2008) Production of beta-cells from human embryonic stem cells. Diabetes Obes. Metab 10 Suppl 4: 186-194.

BLYSZCZUK, P., ASBRAND, C., ROZZO, A., KANIA, G., ST ONGE, L., RUPNIK, M. and WOBUS, A. M. (2004) Embryonic stem cells differentiate into insulinproducing cells without selection of nestin-expressing cells. Int. J. Dev. Biol. 48: 1095-1104.

BLYSZCZUK, P., CZYZ, J., KANIA, G., WAGNER, M., ROLL, U., ST ONGE, L. and WOBUS, A. M. (2003) Expression of Pax4 in embryonic stem cells promotes differentiation of nestin-positive progenitor and insulin-producing cells. Proc. Natl. Acad. Sci. USA 100: 998-1003.

BLYSZCZUK, P. and WOBUS, A. M. (2004) Stem cells and pancreatic differentiation in vitro. J. Biotechnol. 113: 3-13.

BOLSTAD, B. M., IRIZARRY, R. A., ASTRAND, M. and SPEED, T. P. (2003) A comparison of normalization methods for high density oligonucleotide array data based on variance and bias. Bioinformatics. 19: 185-193.

BONAL, C. and HERRERA, P. L. (2008) Genes controlling pancreas ontogeny. Int. J. Dev. Biol. 52: 823-835.

BONNER-WEIR, S. and WEIR, G. C. (2005) New sources of pancreatic beta-cells. Nat. Biotechnol. 23: 857-861.

BOONEN, K., BAGGERMAN, G., D'HERTOG, W., HUSSON, S. J., OVERBERGH, L., MATHIEU, C. and SCHOOFS, L. (2007) Neuropeptides of the islets of Langerhans: a peptidomics study. Gen. Comp Endocrinol. 152: 231-241.

BOYD, A. S., WU, D. C., HIGASHI, Y. and WOOD, K. J. (2008) A Comparison of Protocols used to Generate Insulin-producing Cell Clusters from Mouse Embryonic Stem Cells. Stem Cells 26: 1128-1137.

BRUN, T., FRANKLIN, I., ST ONGE, L., BIASON-LAUBER, A., SCHOENLE, E. J., WOLLHEIM, C. B. and GAUTHIER, B. R. (2004) The diabetes-linked transcription factor PAX4 promotes $\{$ beta\}-cell proliferation and survival in rat and human islets. J. Cel/ Biol. 167: 1123-1135.

BUCHHOLZ, M., BIEBL, A., NEESSE, A., WAGNER, M., IWAMURA, T., LEDER, G., ADLER, G. and GRESS, T. M. (2003) SERPINE2 (protease nexin I) promotes extracellular matrix production and local invasion of pancreatic tumors in vivo. Cancer Res. 63: 4945-4951.

BURKS, D. J. and WHITE, M. F. (2001) IRS proteins and beta-cell function. Diabetes 50 Suppl 1: S140-S145.

CHEN, H., CARLSON, E. C., PELLET, L., MORITZ, J. T. and EPSTEIN, P. N. (2001) Overexpression of metallothionein in pancreatic beta-cells reduces 
streptozotocin-induced DNA damage and diabetes. Diabetes 50: 2040-2046.

CHEN, M., TEMPST, P. and YANKNER, B. A. (1992) Secretogranin I/chromogranin $B$ is a heparin-binding adhesive protein. J. Neurochem. 58: 1691-1698.

CHU, K. and TSAI, M. J. (2005) Neuronatin, a downstream target of BETA2/ NeuroD1 in the pancreas, is involved in glucose-mediated insulin secretion. Diabetes 54: 1064-1073.

CNOP, M., HANNAERT, J. C., GRUPPING, A. Y. and PIPELEERS, D. G. (2002) Low density lipoprotein can cause death of islet beta-cells by its cellular uptake and oxidative modification. Endocrinology 143: 3449-3453.

CONLON, J. M., HOOG, A. and GRIMELIUS, L. (1995) Intracellular degradation of the C-peptide of proinsulin, in a human insulinoma: identification of sites of cleavage and evidence for a role for cathepsin B. Pancreas 10: 167-172.

D'AMOUR, K. A., BANG, A. G., ELIAZER, S., KELLY, O. G., AGULNICK, A. D., SMART, N. G., MOORMAN, M. A., KROON, E., CARPENTER, M. K. and BAETGE, E. E. (2006) Production of pancreatic hormone-expressing endocrine cells from human embryonic stem cells. Nat. Biotechnol. 24: 1392-1401.

DE LISLE, R. C., SARRAS, M. P., Jr., HIDALGO, J. and ANDREWS, G. K. (1996) Metallothionein is a component of exocrine pancreas secretion: implications for zinc homeostasis. Am. J. Physio/271: C1103-C1110.

EISEN, M. B., SPELLMAN, P. T., BROWN, P. O. and BOTSTEIN, D. (1998) Cluster analysis and display of genome-wide expression patterns. Proc. Natl. Acad. Sci. USA 95: 14863-14868.

ENG, L. F., GHIRNIKAR, R. S. and LEE, Y. L. (2000) Glial fibrillary acidic protein: GFAP-thirty-one years (1969-2000). Neurochem. Res. 25: 1439-1451.

ETO, K., YAMASHITA, T., TSUBAMOTO, Y., TERAUCHI, Y., HIROSE, K., KUBOTA, N., YAMASHITA, S., TAKA, J., SATOH, S., SEKIHARA, H., TOBE, K., IINO, M., NODA, M., KIMURA, S. and KADOWAKI, T. (2002) Phosphatidylinositol 3kinase suppresses glucose-stimulated insulin secretion by affecting postcytosolic $[\mathrm{Ca}(2+)]$ elevation signals. Diabetes 51 : 87-97.

GAVAZZI, I. (2001) Semaphorin-neuropilin-1 interactions in plasticity and regeneration of adult neurons. Cell Tissue Res. 305: 275-284.

GORR, S. U., SHIOI, J. and COHN, D. V. (1989) Interaction of calcium with porcine adrenal chromogranin A (secretory protein-I) and chromogranin B (secretogranin I). Am. J. Physio/257: E247-E254.

GU, G., WELLS, J. M., DOMBKOWSKI, D., PREFFER, F., ARONOW, B. and MELTON, D. A. (2004) Global expression analysis of gene regulatory pathways during endocrine pancreatic development. Development 131: 165-179.

HABENER, J. F., KEMP, D. M. and THOMAS, M. K. (2005) Minireview: transcriptional regulation in pancreatic development. Endocrinology 146: 1025-1034.

HANSSON, M., TONNING, A., FRANDSEN, U., PETRI, A., RAJAGOPAL, J., ENGLUND, M. C., HELLER, R. S., HAKANSSON, J., FLECKNER, J., SKOLD, H. N., MELTON, D., SEMB, H. and SERUP, P. (2004) Artifactual insulin release from differentiated embryonic stem cells. Diabetes 53: 2603-2609.

HILL, D. J., HOGG, J., PETRIK, J., ARANY, E. and HAN, V. K. (1999) Cellular distribution and ontogeny of insulin-like growth factors (IGFs) and IGF binding protein messenger RNAs and peptides in developing rat pancreas. J. Endocrinol. 160: 305-317.

HILL, D. J., PETRIK, J. and ARANY, E. (1998) Growth factors and the regulation of fetal growth. Diabetes Care 21 Suppl 2: B60-B69.

HORI, Y., RULIFSON, I. C., TSAI, B. C., HEIT, J. J., CAHOY, J. D. and KIM, S. K. (2002) Growth inhibitors promote differentiation of insulin-producing tissue from embryonic stem cells. Proc. Natl. Acad. Sci. USA 99: 16105-16110.

JACOBSSON, B., COLLINS, V. P., GRIMELIUS, L., PETTERSSON, T., SANDSTEDT, B. and CARLSTROM, A. (1989) Transthyretin immunoreactivity in human and porcine liver, choroid plexus, and pancreatic islets. J. Histochem. Cytochem. 37: 31-37.

JOSEPH, R., DOU, D. and TSANG, W. (1994) Molecular cloning of a novel mRNA (neuronatin) that is highly expressed in neonatal mammalian brain. Biochem. Biophys. Res. Commun. 201: 1227-1234.

KAESTNER, K. H., KATZ, J., LIU, Y., DRUCKER, D. J. and SCHUTZ, G. (1999) Inactivation of the winged helix transcription factor HNF3alpha affects glucose homeostasis and islet glucagon gene expression in vivo. Genes Dev. 13: 495504.

KAIDO, T., YEBRA, M., CIRULLI, V. and MONTGOMERY, A. M. (2004) Regulation of human beta-cell adhesion, motility, and insulin secretion by collagen IV and its receptor alpha1beta1. J. Biol. Chem. 279: 53762-53769.

KANAI-AZUMA, M., KANAI, Y., GAD, J. M., TAJIMA, Y., TAYA, C., KUROHMARU, M., SANAI, Y., YONEKAWA, H., YAZAKI, K., TAM, P. P. and HAYASHI, Y. (2002) Depletion of definitive gut endoderm in Sox17-null mutant mice. Deve/opment 129: 2367-2379.

KANIA, G., BLYSZCZUK, P. and WOBUS, A. M. (2004) The generation of insulinproducing cells from embryonic stem cells-a discussion of controversial findings. Int. J. Dev. Biol. 48: 1061-1064.

KARLSSON, E. (2001) The role of pancreatic chromogranins in islet physiology. Curr. Mol. Med. 1: 727-732.

KATO, M., KATO, K., BLANER, W. S., CHERTOW, B. S. and GOODMAN, D. S. (1985) Plasma and cellular retinoid-binding proteins and transthyretin (prealbumin) are all localized in the islets of Langerhans in the rat. Proc. Natl. Acad. Sci. USA 82: 2488-2492.

KATZ, L. E., BHALA, A., CAMRON, E., NUNN, S. E., HINTZ, R. L. and COHEN, P. (1997) IGF-II, IGF-binding proteins and IGF receptors in pancreatic beta-cell lines. J. Endocrinol. 152: 455-464.

KONINGER, J., GIESE, N. A., DI MOLA, F. F., BERBERAT, P., GIESE, T., ESPOSITO, I., BACHEM, M. G., BUCHLER, M. W. and FRIESS, H. (2004) Overexpressed decorin in pancreatic cancer: potential tumor growth inhibition and attenuation of chemotherapeutic action. Clin. Cancer Res. 10: 4776-4783.

KRESSE, H. and SCHONHERR, E. (2001) Proteoglycans of the extracellular matrix and growth control. J. Cell Physio/189: 266-274.

KROON, E., MARTINSON, L. A., KADOYA, K., BANG, A. G., KELLY, O. G., ELIAZER, S., YOUNG, H., RICHARDSON, M., SMART, N. G., CUNNINGHAM, J., AGULNICK, A. D., D'AMOUR, K. A., CARPENTER, M. K. and BAETGE, E. E. (2008) Pancreatic endoderm derived from human embryonic stem cells generates glucose-responsive insulin-secreting cells in vivo. Nat. Biotechnol. 26: 443-452.

KULIAWAT, R., KLUMPERMAN, J., LUDWIG, T. and ARVAN, P. (1997) Differential sorting of lysosomal enzymes out of the regulated secretory pathway in pancreatic beta-cells. J. Cell Biol. 137: 595-608.

LEON-QUINTO, T., JONES, J., SKOUDY, A., BURCIN, M. and SORIA, B. (2004) In vitro directed differentiation of mouse embryonic stem cells into insulinproducing cells. Diabetologia 47: 1442-1451.

LUMELSKY, N., BLONDEL, O., LAENG, P., VELASCO, I., RAVIN, R. and MCKAY, R. (2001) Differentiation of embryonic stem cells to insulin-secreting structures similar to pancreatic islets. Science 292: 1389-1394.

MARZBAN, L., SOUKHATCHEVA, G. and VERCHERE, C. B. (2005) Role of carboxypeptidase $E$ in processing of pro-islet amyloid polypeptide in \{beta\}cells. Endocrinology 146: 1808-1817.

MFOPOU, J., WILLEMS, E., LEYNS, L. and BOUWENS, L. (2005) Expression of regulatory genes for pancreas development during murine embryonic stem cell differentiation. Int. J. Dev. Biol. 49: 915-922.

MIRALLES, F., LAMOTTE, L., COUTON, D. and JOSHI, R. L. (2006) Interplay between FGF10 and Notch signalling is required for the self-renewal of pancreatic progenitors. Int. J. Dev. Biol. 50: 17-26.

MIYAZAKI, S., YAMATO, E. and MIYAZAKI, J. (2004) Regulated expression of pdx1 promotes in vitrodifferentiation of insulin-producing cells from embryonic stem cells. Diabetes 53: 1030-1037.

NAGY, A., ROSSANT, J., NAGY, R., ABRAMOW-NEWERLY, W. and RODER, J. C. (1993) Derivation of completely cell culture-derived mice from early-passage embryonic stem cells. Proc. Natl. Acad. Sci. USA 90: 8424-8428.

NATORI, S. and HUTTNER, W. B. (1996) Chromogranin B (secretogranin I) promotes sorting to the regulated secretory pathway of processing intermediates derived from a peptide hormone precursor. Proc. Natl. Acad. Sci. USA93: 4431-4436.

NIWA, H., HARRISON, L. C., DEAIZPURUA, H. J. and CRAM, D. S. (1997) Identification of pancreatic beta cell-related genes by representational difference analysis. Endocrinology 138: 1419-1426.

PORTELA-GOMES, G. M. and STRIDSBERG, M. (2002) Region-specific antibodies to chromogranin $B$ display various immunostaining patterns in human endocrine pancreas. J. Histochem. Cytochem. 50: 1023-1030.

RAJAGOPAL, J., ANDERSON, W. J., KUME, S., MARTINEZ, O. I. and MELTON, D. A. (2003) Insulin staining of ES cell progeny from insulin uptake. Science 299: 363. 


\section{A. Rolletschek et al.}

RAJPAL, A., CHO, Y. A., YELENT, B., KOZA-TAYLOR, P. H., LI, D., CHEN, E., WHANG, M., KANG, C., TURI, T. G. and WINOTO, A. (2003) Transcriptional activation of known and novel apoptotic pathways by Nur77 orphan steroid receptor. EMBO J. 22: 6526-6536.

REFAI, E., DEKKI, N., YANG, S. N., IMREH, G., CABRERA, O., YU, L., YANG, G., NORGREN, S., ROSSNER, S. M., INVERARDI, L., RICORDI, C., OLIVECRONA, G., ANDERSSON, M., JORNVALL, H., BERGGREN, P. O. and JUNTTIBERGGREN, L. (2005) Transthyretin constitutes a functional component in pancreatic beta-cell stimulus-secretion coupling. Proc. Natl. Acad. Sci. USA 102: 17020-17025.

ROCHE, E., SEPULCRE, P., REIG, J. A., SANTANA, A. and SORIA, B. (2005) Ectodermal commitment of insulin-producing cells derived from mouse embryonic stem cells. FASEB J. 19: 1341-1343.

ROEHRICH, M. E., MOOSER, V., LENAIN, V., HERZ, J., NIMPF, J., AZHAR, S., BIDEAU, M., CAPPONI, A., NICOD, P., HAEFLIGER, J. A. and WAEBER, G. (2003) Insulin-secreting beta-cell dysfunction induced by human lipoproteins. J. Biol. Chem. 278: 18368-18375.

ROLLETSCHEK, A., KANIA, G. and WOBUS, A. M. (2006) Generation of pancreatic insulin-producing cells from embryonic stem cells - 'proof of principle', but questions still unanswered. Diabetologia 49: 2541-2545.

SCHROEDER, I. S., ROLLETSCHEK, A., BLYSZCZUK, P., KANIA, G. and WOBUS, A. M. (2006) Differentiation of mouse embryonic stem cells to insulin-producing cells. Nat. Protoc. 1: 495-507.

SEABERG, R. M., SMUKLER, S. R., KIEFFER, T. J., ENIKOLOPOV, G., ASGHAR, Z., WHEELER, M. B., KORBUTT, G. and VAN DER, K. D. (2004) Clonal identification of multipotent precursors from adult mouse pancreas that generate neural and pancreatic lineages. Nat. Biotechnol. 22: 1115-1124.

SEGARA, D., BIANKIN, A. V., KENCH, J. G., LANGUSCH, C. C., DAWSON, A. C., SKALICKY, D. A., GOTLEY, D. C., COLEMAN, M. J., SUTHERLAND, R. L. and HENSHALL, S. M. (2005) Expression of HOXB2, a retinoic acid signaling target in pancreatic cancer and pancreatic intraepithelial neoplasia. Clin. Cancer Res. 11: 3587-3596.

SERUP, P. (2006) Embryonic stem cell-based diabetes therapy-a long road to travel. Diabetologia 49: 2537-2540.

SHARMA, S. K., LEINEMANN, U., RATKE, R., OETJEN, E., BLUME, R., DICKEL, C. and KNEPEL, W. (2005) Characterization of a novel Foxa (hepatocyte nuclear factor-3) site in the glucagon promoter that is conserved between rodents and humans. Biochem. J. 389: 831-841.

SHI, Y., HOU, L., TANG, F., JIANG, W., WANG, P., DING, M. and DENG, H. (2005) Inducing embryonic stem cells to differentiate into pancreatic beta cells by a novel three-step approach with activin A and all-trans retinoic acid. Stem Cells 23: 656-662.

SHIMODA, M., KANAI-AZUMA, M., HARA, K., MIYAZAKI, S., KANAI, Y., MONDEN, M. and MIYAZAKI, J. (2007) Sox17 plays a substantial role in late-stage differentiation of the extraembryonic endoderm in vitro. J. Cell Sci. 120: 38593869.

SHIROI, A., UEDA, S., OUJI, Y., SAITO, K., MORIYA, K., SUGIE, Y., FUKUI, H. ISHIZAKA, S. and YOSHIKAWA, M. (2005) Differentiation of embryonic stem cells into insulin-producing cells promoted by Nkx2.2 gene transfer. World $\mathrm{J}$. Gastroenterol. 11: 4161-4166.

SIPIONE, S., ESHPETER, A., LYON, J. G., KORBUTT, G. S. and BLEACKLEY, R. C. (2004) Insulin expressing cells from differentiated embryonic stem cells are not beta cells. Diabetologia 47: 499-508.

SORIA, B. (2001) In-vitro differentiation of pancreatic beta-cells. Differentiation 68 : 205-219.

SORIA, B., ROCHE, E., BERNA, G., LEON-QUINTO, T., REIG, J. A. and MARTIN, F. (2000) Insulin-secreting cells derived from embryonic stem cells normalize glycemia in streptozotocin-induced diabetic mice. Diabetes 49: 157-162.

VACA, P., MARTIN, F., VEGARA-MESEGUER, J. M., ROVIRA, J. M., BERNA, G. and SORIA, B. (2006) Induction of differentiation of embryonic stem cells into insulin-secreting cells by fetal soluble factors. Stem Cells 24: 258-265.

WOBUS, A. M. and BOHELER, K. R. (2005) Embryonic stem cells: prospects for developmental biology and cell therapy. Physiol Rev. 85: 635-678.

WOBUS, A. M., GUAN, K., YANG, H. T. and BOHELER, K. R. (2002) Embryonic stem cells as a model to study cardiac, skeletal muscle, and vascular smooth muscle cell differentiation. Methods Mol. Biol. 185: 127-156.

ZULEWSKI, H., ABRAHAM, E. J., GERLACH, M. J., DANIEL, P. B., MORITZ, W., MULLER, B., VALLEJO, M., THOMAS, M. K. and HABENER, J. F. (2001) Multipotential nestin-positive stem cells isolated from adult pancreatic islets differentiate ex vivo into pancreatic endocrine, exocrine, and hepatic phenotypes. Diabetes 50: 521-533. 


\section{Further Related Reading, published previously in the Int. J. Dev. Biol.}

See Special Issue Pattern Formation edited by Michael K. Richardson and Cheng-Ming Chuong at: http://www.ijdb.ehu.es/web/contents.php?vol=53\&issue=5-6

Apo-14 is required for digestive system organogenesis during fish embryogenesis and larval development Jian-Hong Xia, Jing-Xia Liu, Li Zhou, Zhi Li and Jian-Fang Gui

Int. J. Dev. Biol. (2008) 52: 1089-1098

Spatiotemporal expression of the selenoprotein $\mathbf{P}$ genein postimplantational mouse embryos Se-Ra Lee, Jung-Min Yon, In-Jeoung Baek, Mi-Ra Kim, Chun-Gui Park, Beom-Jun Lee, Young-Won Yun and Sang-Yoon Nam Int. J. Dev. Biol. (2008) 52: 1005-1011

Genes controlling pancreas ontogeny

Claire Bonal and Pedro L. Herrera

Int. J. Dev. Biol. (2008) 52: 823-835

Differentiation of human embryonic stem cells into hepatocytes in 2D and 3D culture systems in vitro Hossein Baharvand, Seyed M. Hashemi, Saeid Kazemi Ashtiani and Ali Farrokhi Int. J. Dev. Biol. (2006) 50: 645-652

C/EBPalpha and C/EBPbeta are markers of early liver development

Adam Westmacott, Zoë D. Burke, Guillermo Oliver, Jonathan M.W. Slack and David Tosh Int. J. Dev. Biol. (2006) 50: 653-657

Interplay between FGF10 and Notch signalling is required for the self-renewal of pancreatic progenitors

Francisco Miralles, Luciane Lamotte, Dominique Couton and Rajiv L. Joshi

Int. J. Dev. Biol. (2006) 50: 17-26

Expression of regulatory genes for pancreas development during murine embryonic stem cell differentiation

Josué K. Mfopou, Erik Willems, Luc Leyns and Luc Bouwens

Int. J. Dev. Biol. (2005) 49: 915-922

Embryonic stem cells differentiate into insulin-producing cells without selection of nestin-expressing cells

Przemyslaw Blyszczuk, Christian Asbrand, Aldo Rozzo, Gabriela Kania, Luc St-Onge, Marjan Rupnik and Anna M. Wobus

Int. J. Dev. Biol. (2004) 48: 1095-1104

The generation of insulin-producing cells from embryonic stem cells - a discussion of controversial findings

Gabriela Kania, Przemyslaw Blyszczuk and Anna M. Wobus

Int. J. Dev. Biol. (2004) 48: 1061-1064

Efficient Cre-mediated deletion in cardiac progenitor cells conferred by a 3'UTR-iresCre allele of the homeobox gene Nkx2-5

Edouard G Stanley, Christine Biben, Andrew Elefanty, Louise Barnett, Frank Koentgen, Lorraine Robb and Richard P Harvey

Int. J. Dev. Biol. (2002) 46: 431-439

Pancreatic lineage analysis using a retroviral vector in embryonic mice demonstrates a common progenitor for endocrine and exocrine cells

Martha P Fishman and Douglas A Melton

Int. J. Dev. Biol. (2002) 46: 201-207

Defining the cell lineages of the islets of Langerhans using transgenic mice

Pedro L Herrera

Int. J. Dev. Biol. (2002) 46: 97-103

Role of cell division in branching morphogenesis and differentiation of the embryonic pancreas

L D Horb and J M Slack

Int. J. Dev. Biol. (2000) 44: 791-796

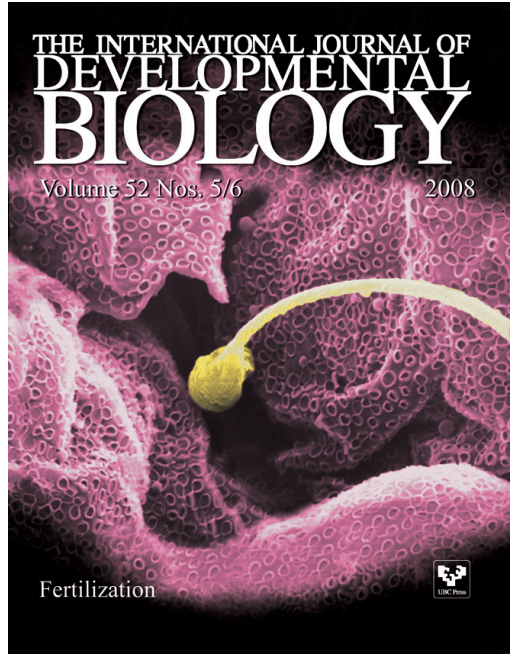

5 yr ISI Impact Factor $(2008)=3.271$

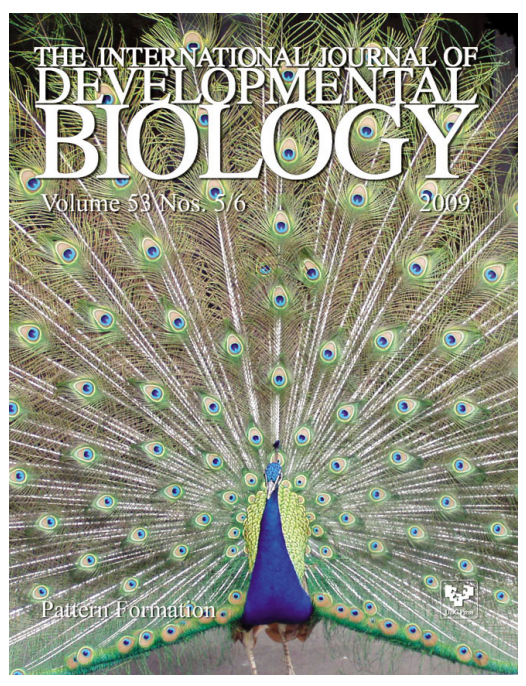

